\title{
The Molecular Basis of NMDA Receptor Subtypes: Native Receptor Diversity Is Predicted by Subunit Composition
}

\author{
Amy L. Buller, ${ }^{1}$ Heidi C. Larson, ${ }^{1}$ Benjamin E. Schneider, ${ }^{1}$ Jean A. Beaton, ${ }^{1}$ Richard A. Morrisett, ${ }^{1}$ and Daniel T. \\ Monaghan ${ }^{1,2}$ \\ 1Department of Pharmacology and 'Division of Neurology, Department of Internal Medicine, University of Nebraska \\ Medical Center, Omaha, Nebraska 68198-6260
}

The relationship between four pharmacologically distinct NMDA receptor subtypes, identified in radioligand binding studies, and the recently identified NMDA receptor subunits (NR1a-g, NR2A-D) has not been determined. In this report, we demonstrate that the anatomical distribution of the four NMDA receptor subtypes strikingly parallels the distribution of mRNA encoding NR2A-D subunits. The distribution of NR2A mRNA was very similar to that of "antagonist-preferring" NMDA receptors [defined by high-affinity ${ }^{3} \mathrm{H}-2$-carboxypiperazine-4-yl-propyl-1-phosphonic ( ${ }^{3} \mathrm{H}-\mathrm{CPP}$ ) binding sites; correlation coefficient $=0.881$. Agonist-preferring NMDA receptors localized to brain regions expressing both NR2B mRNA and NR1 - mRNA (NR1 splice variant lacking insert 1). NR2C mRNA was largely restricted to the cerebellar granule cell layer, a region that displays a unique pharmacological profile. NR2D mRNA localized exclusively to those diencephalic nuclei that have a fourth, distinct pharmacological profile (typified by the midline thalamic nuclei).

The pharmacology of native NMDA receptors was compared to that of heteromeric NMDA receptors expressed in Xenopus oocytes (NR1/NR2A, NR1/NR2B, NR1/NR2C). The oocyte-expressed NR1/NR2A receptor displayed a higher affinity for antagonists and a slightly lower affinity for agonists than the NR1/NR2B receptor. These patterns are analogous to those found for radioligand binding to native receptors in the lateral thalamus and medial striatum, respectively. NMDA receptors in the lateral thalamus (with a high density of NR2A subunit mRNA) displayed higher affinity for antagonists and a lower affinity for agonists than did NMDA receptors of the medial striatum (a region rich in NR2B mRNA). Relative to the NR1/NR2A and NR1/NR2B receptors, oocyte-expressed NR1/NR2C receptors had a lower affinity specifically for both D-3-(2-carboxypiperazin-4-yl)-1propenyl-1-phosphonic acid (D-CPPene) and homoquinolinate (HQ). This pattern was identical to that observed for cerebellar (NR2C-containing) versus forebrain (NR2A- and NR2B-containing) NMDA receptors. Taken together, the data in this report suggest that the four previously identified na-

\footnotetext{
Received Oct. 29, 1993; revised Mar. 1, 1994; accepted Mar. 15, 1994.

This work was supported by NIH Grant NS 28966. We thank Dr. Shigetada Nakanishi and Dr. Peter Seeburg for their generous gifts of NR 1 and NR2 cDNAs, respectively. We also thank Dr. Jeff Watkins for providing several compounds, including homoquinolinate, and Dr. Paul Herrling for providing D-CPPene.

Correspondence should be addressed to Dr. Daniel T. Monaghan, Department of Pharmacology, University of Nebraska Medical Center, 600 South 42 Street, Omaha, NE 68198-6260.

Copyright $(1) 1994$ Society for Neuroscience $0270-6474 / 94 / 145471-14 \$ 05.00 / 0$
}

tive NMDA receptor subtypes differ in their NR2 composition. Furthermore, the NR2 subunits significantly contribute to the anatomical and pharmacological diversity of NMDA receptor subtypes.

[Key words: NMDA, oocytes, in situ hybridization, recombinant DNA, receptors, glutamate, autoradiography, voltage clamp]

NMDA receptors mediate synaptic transmission and neural plasticity at many sites in the mammalian CNS (Mayer and Westbrook, 1987; Collingridge and Lester, 1989; Monaghan et al., 1989) and also contribute to epileptiform activity and neuronal cell death in a number of experimental and pathological conditions (Cotman et al., 1989; Greenamyre and Young, 1989; Meldrum and Garthwaite, 1990). The identification and molecular characterization of functionally distinct NMDA receptor subtypes will contribute to a better understanding of the specific role of these receptors in many normal and pathological conditions.

Recently, two families of NMDA receptor subunits (NR1ag, corresponding to NR 1 A-G, Sugihara et al., 1992; and NR2AD) have been cloned and sequenced from rat (Moriyoshi et al., 1991; Monyer et al., 1992; Ishii et al., 1993) and mouse (Ikeda et al., 1992; Kutsuwada et al., 1992; Meguro et al., 1992; Yamazaki et al., 1992). Alternative splicing of a single NR1 gene generates eight isoforms with distinct functional properties (Anantharam et al., 1992; Durand et al., 1992, 1993; Nakanishi et al., 1992; Sugihara et al., 1992; Hollmann et al., 1993). Heterogeneity within the NR2 subunit family results from expression of four closely related genes (Kutsuwada et al., 1992; Monyer et al., 1992; Ishii et al., 1993). Native NMDA receptors are believed to be heteromeric complexes. While the NR 1 subunit can form functional homo-oligomeric receptors, coexpression of NR1 with NR2A, NR2B, or NR2C in vitro greatly enhances responses to NMDA (Kutsuwada et al., 1992; Meguro et al., 1992; Monyer et al., 1992; Ishii et al., 1993).

Heterogeneity of NMDA receptors has been suggested by previous pharmacological studies. Results from radioligand binding and electrophysiological studies have identified four pharmacologically distinct populations of NMDA receptors. Two of these populations are typified by NMDA receptors found in the cerebellum (Perkins and Stone, 1983; Sekiguchi et al., 1990; Ebert et al., 1991; Monaghan and Beaton, 1991; O'Shea et al., 1991; Beaton et al., 1992) and the medial thalamic nuclei (Beaton et al., 1992), which display distinct pharmacological profiles at both the glutamate and channel blocker binding sites. The two remaining groups of NMDA receptors differ in their relative 
affinities for agonists and antagonists (Monaghan et al., 1988; Monaghan, 1991; Sakurai et al., 1993) as well as in specific biochemical properties (Honoré et al., 1989; Cunningham and Michaelis, 1990; Ogita et al., 1991). Examples of these NMDA receptor subtypes are the NMDA receptors in the ventral posterior nucleus of the lateral thalamus that display a relatively high affinity for antagonists (antagonist-preferring receptor) and those of the medial striatum that display a higher affinity for agonists (agonist-preferring receptor). The objective of the present study was to determine the relationship between the identified receptor subunits and the native NMDA receptor subtypes. We now report that the pharmacologically distinct NMDA receptor subtypes colocalize with specific NR 2 subunit mRNAs. Furthermore, the native NMDA receptor pharmacology can be reproduced with the corresponding combination of recombinant NMDA receptor subunits expressed in Xenopus oocytes. The data in this report demonstrate that the pharmacological and anatomical differences between native NMDA receptor subtypes depend significantly on the particular type of NR2 subunit present in the NR1/NR2 heteromer.

\section{Materials and Methods}

Quantitative receptor autoradiography. Brains were removed from adult male Sprague-Dawley rats (200-250 gm) and immediately frozen. Sections $(6 \mu \mathrm{m})$ were cut in a cryostat, thaw mounted onto gelatin-subbed slides, and refrozen. $\mathrm{L}_{-}{ }^{3} \mathrm{H}$-Glutamate binding to NMDA receptors was performed as previously described (Monaghan and Beaton, 1991). Briefly, slides were washed for $15-30 \mathrm{~min}$ at $0^{\circ} \mathrm{C}$ in $50 \mathrm{~mm}$ Tris acetate, $\mathrm{pH}$ 7.0 , and preincubated twice for $10 \mathrm{~min}$ at $30^{\circ} \mathrm{C}$ in $50 \mathrm{~mm}$ Tris acetate, $\mathrm{pH}$ 7.0. NMDA receptors were selectively labeled by incubation in 50 nM L- $\left[{ }^{3} \mathrm{H}\right]$-glutamate $(54.7 \mathrm{Ci} / \mathrm{mmol}$; New England Nuclear, Boston, MA) in buffer containing $50 \mathrm{~mm}$ Tris acetate, $\mathrm{pH} 7.0,10 \mu \mathrm{M}$ glycine, 5 $\mu \mathrm{M}$ amino-3-hydroxy-isoxazole-4-propionate (AMPA), $1 \mu \mathrm{M}$ kainate, and $100 \mu \mathrm{M}$ 4-acetamido-4'-isothiocyano-2',2-disulfonic acid stilbene for $20 \mathrm{~min}$ at $0^{\circ} \mathrm{C}$ to displace all non-NMDA receptor binding. Agonist and antagonist competitors were added as indicated in the Results. NMDA-specific binding (defined as binding displaced by $500 \mu \mathrm{M}$ NMDA) represented $>95 \%$ of the $\mathrm{L}^{-3} \mathrm{H}$-glutamate-specific binding. ${ }^{3} \mathrm{H}-( \pm)-2-$ carboxypiperazine-4-yl-propyl-1-phosphonic acid ( ${ }^{3} \mathrm{H}-\mathrm{CPP} ; 25 \mathrm{Cj} / \mathrm{mmol}$; New England Nuclear, Boston, MA) autoradiography was performed as described (Monaghan et al., 1988). Following two 10 min preincubations at $30^{\circ} \mathrm{C}$, slide-mounted sections were incubated in $50 \mathrm{~mm}$ Tris- $\mathrm{Cl}$, containing $100 \mathrm{~nm}{ }^{3} \mathrm{H}$-CPP for $20 \mathrm{~min}$ at $0^{\circ} \mathrm{C}$. Sections were washed for $20 \mathrm{sec}$ and placed against ${ }^{3} \mathrm{H}$-sensitive film (Hyperfilm ${ }^{3} \mathrm{H}$, Amersham, Arlington Heights, IL) with ${ }^{3} \mathrm{H}$ standards (Microscales, Amersham, Arlington Heights, IL). Dose-response curves generated for competitors of $\mathrm{L}^{3}{ }^{3} \mathrm{H}$-glutamate binding in the three brain regions described (lateral thalamus, medial striatum, and cerebellar granule cell layer) were determined by computer-assisted image analysis of the autoradiograms (MCID, Imaging Research, St. Catharines, Ontario, Canada). Dose-response relationships were analyzed by iterative, nonlinear regression analysis using a modification of the method of Marquardt (GRAPHPAD, ISI Software, San Diego, CA) with the goodness of fit assessed by the sum of the squares of the absolute deviation from the curve for untransformed one- and two-site competitive binding curves (for equations, see Ehlert and Tran, 1990). The Cheng-Prusoff (1973) equation was used to correct for regional variations in $\mathrm{L}^{-3} \mathrm{H}$-glutamate affinity (Monaghan and Beaton, 1991). Chemicals were from Sigma (St. Louis, $\mathrm{MO}$ ) and Tocris (Essex, UK). All experiments were performed at least four times and representative dose-response curves are shown.

Oligonucleotide probes. Sequences for antisense oligonucleotide probes specific for NR2A, NR2B, and NR2C were from Monyer et al. (1992). In addition, the following sequences were also used: NR2D, $5^{\prime}$-CTC. CGAA TCCTCGGAGTCCGAAGGCGAAGGCTCGAGGTCC AGGTA-3' [complementary to sequences encoding amino acids 10671081 of the $\epsilon 4$ subunit (Ikeda et al., 1992) and differs by one nucleotide from the corresponding rat sequence (Ishii et al., 1993)]; NR1 +, 5'GGGTCCGCGCTTGTTGTCATAGGACAGTTGGTCGAGGTT. TTCATA-3' [complementary to sequences encoding amino acids $6-20$ of insert 1 sequence (Sugihara et al., 1992)]; NR 1-, 5'-AAACTGCAGCACCTTCTCTGCCTTGGACTCCCGTTCCTCCAG-3' [complementary to sequences encoding amino acids 184-197 of NR la which flank the insert 1 insertion site (Sugihara et al., 1992)]

Oligonucleotides were $3^{\prime}$ end labeled with $\alpha^{-{ }^{35}}$ S-dATP using terminal deoxynucleotidyl transferase (New England Nuclear, Boston, MA). Unincorporated nucleotide was removed by Nensorb chromatography (New England Nuclear, Boston, MA).

In situ hybridization. Adult male Sprague-Dawley rats were sacrificed and brains were removed and immediately frozen on dry ice. Sections $(12 \mu \mathrm{m})$ were thaw mounted, air dried, and fixed for $5 \mathrm{~min}$ in $4 \%$ paraformaldehyde at $4^{\circ} \mathrm{C}$ (Wisden et al., 1991). Slide-mounted sections were washed in phosphate-buffered saline and dehydrated in $70 \%$ ethanol prior to storage in $95 \%$ ethanol. Hybridizations were performed as described by Wisden et al. (1991). ${ }^{35}$ S-labeled oligonucleotide probe was dissolved in hybridization buffer $(2000 \mathrm{cpm} / \mu \mathrm{l}, \sim 0.2 \mathrm{nM}$; New England Nuclear, Boston, MA) containing $0.2 \mathrm{~m}$ DTT and applied to sections. Sections were hybridized overnight under Parafilm-sealed coverslips at $42^{\circ} \mathrm{C}$ (except NR 1 - probe, which was incubated at $50^{\circ} \mathrm{C}$ ) and then washed for $20 \mathrm{~min}$ at a final stringency of $1 \times \operatorname{SSC}(0.015 \mathrm{M}$ sodium citrate, $0.15 \mathrm{M} \mathrm{NaCl})$ at $60^{\circ} \mathrm{C}\left(70^{\circ} \mathrm{C}\right.$ for $\mathrm{NR} 1-$ probe $)$. Sections were air dried and exposed to film ( $\beta$ Max; Amersham, Arlington Heights, IL). Exposure time varied for the different probes and is indicated in the figure legends.

Probe specificity was confirmed by incubation of the radiolabeled oligonucleotides with $100 \mathrm{~nm}$ unlabeled probe. Only oligonucleotides with the same sequence inhibited probe hybridization. Results of in situ hybridization using NR2A-D and NR1 + probes were consistent with previous reports (Monyer et al., 1992; Watanabe et al., 1992; Ishii et al., 1993; Standaert et al., 1993). Cross-hybridization of the NR1 probe to NR1 + mRNA was prevented by increasing the incubation and wash temperatures to $50^{\circ} \mathrm{C}$ and $70^{\circ} \mathrm{C}$, respectively. This selectively reduced NR 1 - probe hybridization to brain regions containing high densities of NRI + mRNA (e.g., thalamus and layer 4 of the parietal cortex).

Quantitative analysis of autoradiograms. Anatomical observations were confirmed by computer-assisted image analysis of the autoradiograms (MCID, Imaging Research, St. Catharines, Ontario, Canada) that were calibrated by either ${ }^{3} \mathrm{H}$-Microscales (for ${ }^{3} \mathrm{H}-\mathrm{CPP}$ and $\mathrm{L}-\left[{ }^{3} \mathrm{H}\right]-\mathrm{glu}$ tamate) or ${ }^{35} \mathrm{~S}$ brain paste standards as previously described (Siegel, 1989) for in situ hybridization autoradiograms. To quantify the correlation between NMDA receptor subunits and NMDA receptor binding sites, the signal intensity in 32 brain regions were determined for in situ hybridization and receptor-radioligand binding autoradiograms. The density values for each animal were normalized to the density found in the parietal cortex and then averaged between animals (prior normalization greatly reduces interexperiment error; Monaghan and Beaton, 1991). Correlation coefficients were determined for the correlations between NMDA receptor subunits (NR2A, NR2B, NR1+, and NR1-) and NMDA receptor binding sites ( ${ }^{3} \mathrm{H}-\mathrm{CPP}$ binding sites and NMDAspecific $\mathrm{L}^{-}{ }^{-} \mathrm{H}$-glutamate binding sites)

In vitro transcription. pN60 containing the $4.2 \mathrm{~kb}$ NR $1 \mathrm{cDNA}$ (Moriyoshi et al., 1991) was the generous gift of Dr. Shigetada Nakanishi (Kyoto University Faculty of Medicine, Kyoto, Japan). This cDNA corresponds to the predominant splice variant found in the CNS, NR1A (Sugihara et al., 1992) and NR 1-SL (Anantharam et al., 1992). cDNAs encoding NR2A, NR2B, and NR2C (Monyer et al., 1992), generously provided by Dr. Peter Seeburg (University of Heidelberg, Heidelberg, Germany), were linearized by digestion with NotI (NR1), EcoRI (NR2A and NR2C), or EcoRV (NR2B) and transcribed in vitro using T3 (NR2A, NR2B, NR2C) or T7 (NR1) RNA polymerase as described (Buller and White, 1988).

Translation in Xenopus oocytes. Oocytes were removed from mature Xenopus laevis (Xenopus One, Ann Arbor, MI) and were dissociated in $2 \mathrm{mg} / \mathrm{ml}$ collagenase (type IA, Sigma Chemical, St. Louis, $\mathrm{MO}$ ) in $\mathrm{Ca}^{2+}$. free OR-2 $(82.5 \mathrm{~mm} \mathrm{NaCl}, 2.5 \mathrm{~mm} \mathrm{KCl}, 1 \mathrm{~mm} \mathrm{MgCl}, 5 \mathrm{mM}$ HEPES, $\mathrm{pH} 7.6)$ and the remaining follicle layer was removed manually. Isolated stage $\mathrm{V}$ and stage $\mathrm{VI}$ oocytes were maintained in ND-96 $(96 \mathrm{~mm} \mathrm{NaCl}$, $2 \mathrm{~mm} \mathrm{KCl}, 1.8 \mathrm{~mm} \mathrm{CaCl}_{2}, 1 \mathrm{~mm} \mathrm{MgCl}_{2}, 5 \mathrm{~mm}$ HEPES, pH 7.6) supplemented with $2.5 \mathrm{~mm}$ sodium pyruvate, $1000 \mathrm{U} / \mathrm{ml}$ penicillin, 0.1 $\mathrm{mg} / \mathrm{ml}$ streptomycin (White et al., 1985). NMDA receptor RNAs were dissolved in sterile distilled $\mathrm{H}_{2} \mathrm{O}$. NR1 RNA was mixed in equimolar stoichiometry with either NR2A, NR2B, or NR2CRNA. The final RNA mixture $(50 \mathrm{nl})$ was microinjected $(15-30 \mathrm{ng}$ total) into the oocyte cytoplasm as previously described (White et al., 1985). Oocytes were 
incubated in complete ND-96 solution at $19^{\circ} \mathrm{C}$ for $1-4 \mathrm{~d}$ prior to electrophysiological assay.

Electrophysiology. Electrophysiological responses were measured using a standard two-microelectrode voltage clamp (model OC-725A oocyte clamp, Warner Instruments, Hamden, CT). Electrodes were filled with $3 \mathrm{M} \mathrm{KCl}$ and had resistances of $0.6-3.0 \mathrm{M} \Omega$. The recording chamber was continuously perfused with $116 \mathrm{~mm} \mathrm{NaCl}, 2 \mathrm{mM} \mathrm{KCl}, 0.5 \mathrm{~mm}$

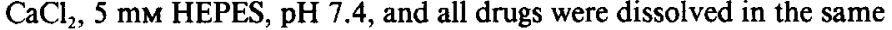
solution. Whole cell current elicited by bath application of NMDA receptor ligands in the presence of $10 \mu \mathrm{M}$ glycine was determined at a holding potential of $-60 \mathrm{mV}$. Only healthy oocytes with a minimum resting potential of $-30 \mathrm{mV}$ were used. Dose-response curves for agonist activation of heteromeric NMDA receptor complexes expressed in oocytes were fit (GRAPHPAD, ISI Software, San Diego, CA) according to the equation $I=I_{\max } /\left[1+\left(\mathrm{EC}_{30} / A\right)^{n}\right]$, where $I$ is the current response, $I_{\max }$ is the current response evoked at maximal agonist concentration, $A$ is the agonist concentration, $n$ is the Hill coefficient, and $\mathrm{EC}_{50}$ is the concentration of agonist producing a half-maximal response. Antagonist inhibition curves were fit by the equation $I=I_{\max }-I_{\max } /\left[1+\left(\mathrm{IC}_{50} /\right.\right.$ $\left.A)^{n}\right]$, where $I$ is the current response in the presence of antagonist, $I_{\max }$ is the control current response in the absence of antagonist, and $A$ is the antagonist concentration. $\mathrm{IC}_{50}$ values were corrected for agonist affinity as described (Durand et al., 1992).

Microinjection of NR1 RNA in combination with NR2A, NR2B, or NR2C RNA resulted in expression of NMDA-gated ion channels in Xenopus oocytes. In all cases, currents elicited by heteromeric NMDA receptors were 10-100 times larger than currents mediated by homomeric NR1 receptors (data not shown). Typical current responses for heteromeric NMDA receptors expressed in oocytes assayed in the presence of $100 \mu \mathrm{M}$ NMDA and $10 \mu \mathrm{M}$ glycine were approximately $100 \mathrm{nA}$ (NR1/NR2A), $20 \mathrm{nA}$ (NR1/NR2B), and $200 \mathrm{nA}$ (NR1/NR2C). The somewhat lower macroscopic currents in this report, relative to other reports (e.g., Monyer et al., 1992) were most likely due to the low calcium concentration used in the recording solutions. $\mathrm{Ca}^{2+}$ entry through NMDAgated channels expressed in oocytes has been shown to activate endogenous $\mathrm{Ca}^{2+}$ activated $\mathrm{Cl}^{-}$currents. This endogenous current is responsible for a large part of both the initial and prolonged phases of the NMDA response in oocytes (Leonard and Kelso, 1990). Reduction of the $\mathrm{Ca}^{2+}$ concentration in the perfusion solution reduces both components of the NMDA response in oocytes (Leonard and Kelso, 1990).

\section{Results}

Comparison between the distributions of agonist-preferring/ antagonist-preferring $N M D A$ receptor subtypes and $N M D A$ receptor subunits

The anatomical localizations of agonist-preferring and antagonist-preferring NMDA receptor populations identified by radioligand binding studies are shown in Figure 1. As described previously (Monaghan et al., 1988; Monaghan, 1991), the NMDA antagonist ${ }^{3} \mathrm{H}$-2-carboxypiperazine-4-yl-propyl-1-phosphonic ( $\left.{ }^{3} \mathrm{H}-\mathrm{CPP}\right)$ and the NMDA agonist $\mathrm{L}^{-3} \mathrm{H}$-glutamate label distinct NMDA receptor populations, referred to as antagonist-preferring and agonist-preferring, respectively. In this report we have compared, in detail, the distributions of these two binding sites to the distributions of NMDA receptor subunit mRNAs. Striking parallels were observed between the localization of NR2A, NR2B, NR1 + (NR1 splice variant with insert 1), and NR1 (NR1 splicc variant lacking insert 1) mRNAs and the agonist/ antagonist-preferring binding sites. In contrast, the distribution of antagonist-preferring and agonist-preferring NMDA receptor binding sites displayed no similarity to NR2C or NR2D mRNA distributions (compare Figs. 1, 6). Agonist-preferring sites (as well as the pharmacologically distinct cerebellar and midline thalamic NMDA receptors) were preferentially labeled by $\mathrm{L}^{-3} \mathrm{H}-$ glutamate both in the presence and absence of $6 \mu \mathrm{M} \mathrm{D}-2$-amino5-phosphonopentanoate (D-AP5). The description below for agonist-preferring sites was consistent with both conditions and was confirmed by quantitative image analysis.
Cerebral cortex. High levels of NMDA-sensitive $\mathrm{L}^{3}{ }^{3} \mathrm{H}$-glutamate binding sites (agonist-preferring) were evident in the anterior cingulate, insular, and perirhinal cortices, with lower levels in the parietal and temporal cortices (Fig. 1B). ${ }^{3} \mathrm{H}-\mathrm{CPP}$ binding sites (antagonist-preferring), in contrast, displayed a more subtle regional variation with a slightly higher density in the parietal and temporal cortical regions than in the anterior cingulate, insular, and perirhinal cortices (Figs. 1 $A, 3$ ). Cortical lamination patterns also differed: while the distribution of agonist-preferring NMDA receptors (receptors preferentially labeled by $\mathrm{L}^{-3} \mathrm{H}$-glutamate) showed a marked laminar variation with higher densities in layers I-III and in layer Va of parietal cortex, ${ }^{3} \mathrm{H}$-CPP binding sites displayed less laminar variation with slightly greater binding in layers I-V than in layer VI. Thus, layer IV displayed the greatest difference between $\mathrm{L}^{3} \mathrm{H}$-glutamate and ${ }^{3} \mathrm{H}$-CPP binding sites with a high density of ${ }^{3} \mathrm{H}-\mathrm{CPP}$ binding sites and a low density of $\mathrm{L}^{3} \mathrm{H}$-glutamate sites (compare Fig. $1 A, B)$. In the entorhinal cortex, higher levels of ${ }^{3} \mathrm{H}-\mathrm{CPP}$ binding sites were found in two superficial layers (separated by layer II) while $\mathrm{L}^{-3}$ II-glutamate binding sites were of lower and more uniform density.

The cortical distribution of NR2A and NR2B mRNA paralleled the distribution of antagonist- and agonist-preferring binding sites, respectively. As found for ${ }^{3} \mathrm{H}-\mathrm{CPP}$ binding sites, high levels of mRNA encoding NR2A were detected in the parietal, entorhinal (superficial layers), and temporal cortices and lower levels in the anterior cingulate, insular, and perirhinal cortices (Figs. 2A, 3). In contrast, higher levels of NR2B mRNA were observed in the anterior cingulate, insular, and perirhinal cortices than in the parietal, temporal, and entorhinal cortices (Fig. 2B). NR2A and NR2B mRNA also differed in their lamination pattern in the parietal cortex. Greater densities of NR2A subunits were found in layers II-IV than in layers V and VI. NR2B mRNA was present at higher levels in layers II-III than in IV-VI (Figs. 2, 3). Thus, layer IV displayed relatively high levels of NR2A mRNA and low levels of NR2B mRNA. Overall, both the regional and laminar variations in antagonist-preferring and agonist-preferring NMDA receptors paralleled the distribution of NR2A and NR2B mRNA, respectively.

NR $1+$ mRNA density varied widely across cortical regions (Figs. 2C,3). Parietal, temporal, and superficial entorhinal cortices displayed approximately threefold higher levels of NR $1+$ mRNA than the anterior cingulate, perirhinal, insular, and pyriform cortices. In contrast, higher levels of NR $1-$ mRNA were found in the anterior cingulate, perirhinal, and insular cortices. Thus, the localization of NR1 + and NR1 - mRNA between cortical regions parallels the distribution of antagonist-preferring and agonist-preferring NMDA receptors, respectively. However, lamination patterns within a defined cortical region partially differ between NR1 + mRNA and receptor subtypes. While a high density of ${ }^{3} \mathrm{H}-\mathrm{CPP}$ binding sites were found in layers II-IV, NR 1 + mRNA was found enriched in layers IV, $\mathrm{Vb}$, and VI. Thus, in layers II-III, there is a high density of ${ }^{3} \mathrm{H}-$ CPP binding sites (and NR2A mRNA), but a low density of $\mathrm{NR} 1+$.

Basal ganglia. The distribution of agonist-preferring NMDA receptors displayed a modest medial-to-lateral gradient within the striatum (Figs. 1 $B, 3$ ). The opposite pattern was observed for ${ }^{3} \mathrm{H}-\mathrm{CPP}$ binding sites, with higher levels in the lateral striatum than in the medial striatum (Fig. 1A, 3). In the nucleus accumbens, a high density of $\mathrm{L}^{-}{ }^{3} \mathrm{H}$-glutamate binding sites were observed in both the core and shell regions. ${ }^{3} \mathrm{H}-\mathrm{CPP}$ binding 

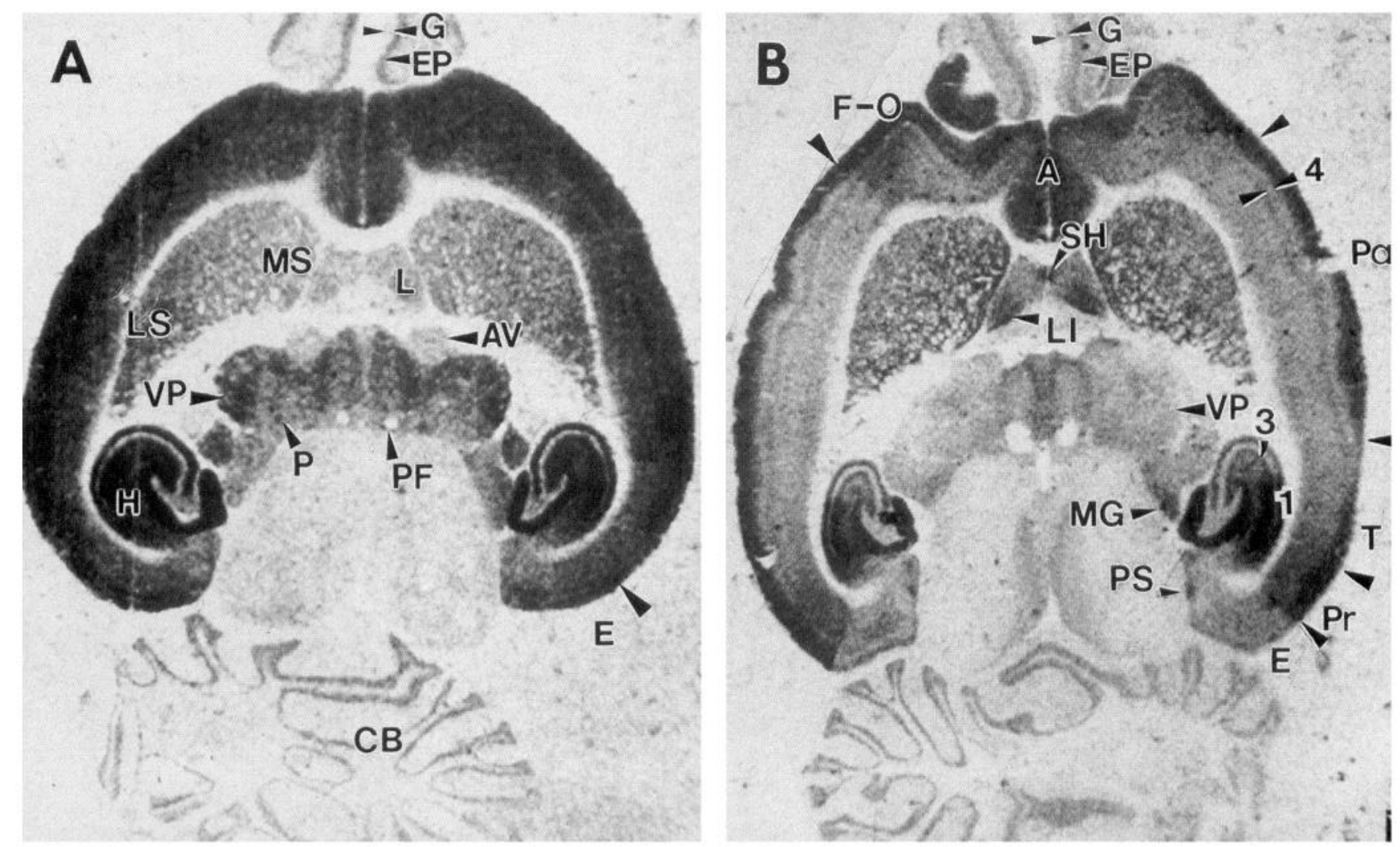

Figure 1. Autoradiography of ${ }^{3} \mathrm{H}-\mathrm{CPP}$ binding sites (antagonist-preferring) $(A)$ and L- ${ }^{3} \mathrm{H}$-glutamate binding sites (predominantly agonist-preferring sites) $(B)$ in horizontal sections of rat brain. Note the relatively low levels of ${ }^{3} \mathrm{H}-\mathrm{CPP}$ binding sites in the medial striatum $(M S)$, lateral septum $(L)$, anteroventral nucleus $(A V)$, and olfactory bulb glomerular layer $(G)$, and the relatively high levels of ${ }^{3} \mathrm{H}$-CPP binding in the ventroposterior nucleus $(V P)$, entorhinal cortex $(E)$, and parietal cortex layer $4(P a, 4)$. 1, CA1 of hippocampus; 3, CA3 of hippocampus; $A$, anterior cingulate; $C B$, cerebellum; $E P$, external plexiform layer of the olfactory bulb; $F-O$, frontal-orbital cortices; $H$, hippocampus; $L I$, lateral septum, intermediate region; $M G$, medial geniculate; $P$, posterior nucleus; $P F$, parafascicular nucleus; $P r$, perirhinal cortex; $S H$, septohippocampal nucleus; $P S$, presubiculum/parasubiculum; $T$, temporal cortex.

sites were present at a higher density in the nucleus accumbens shell than in the core region. As found for ${ }^{3} \mathrm{H}-\mathrm{CPP}$ binding sites, NR2A subunit mRNA was distributed in a distinct lateral to medial gradient within the striatum, with notably higher levels in the shell of the accumbens than in the core region. NR2B mRNA was found at high levels throughout the striatum and accumbens, analogous to the agonist-preferring receptor distribution.

NR1 + mRNA displayed a lateral to medial striatal distribution that was generally similar to NR2A mRNA and antagonist-preferring NMDA receptors (Figs. $2 C, 3$ ). However, unlike the distribution of NR2A mRNA and antagonist-preferring NMDA binding sites, NR1 + mRNA was low throughout the nucleus accumbens. The density of NR 1 - mRNA was modestly higher $(15 \%)$ in the medial striatum than in the lateral striatum, and high levels of this transcript were found in both the core and shell regions of the accumbens. Thus, in the basal ganglia, the distribution of antagonist-preferring binding sites parallels that of NR2A mRNA but only partially agrees with NR1+ mRNA. The distribution of agonist-preferring binding sites corresponds to both NR2B and NR1 - mRNAs.

Septal nuclei. Compared to other brain regions, low levels of ${ }^{3} \mathrm{H}$-CPP binding sites were present in the lateral septum (Fig. $1 A$ ). Within the lateral septum, the lowest levels of ${ }^{3} \mathrm{H}-\mathrm{CPP}$ binding sites were found in the intermediate lateral septum, ventral lateral septum, and septohippocampal nucleus, while higher levels of ${ }^{3} \mathrm{H}-\mathrm{CPP}$ binding were observed in the dorsal lateral septum. The lateral septum had a relatively high density of $\mathrm{L}^{-3} \mathrm{H}$-glutamate binding sites (Figs. $1 B, 3$ ). Within the lateral septum, higher levels of ${ }^{3} \mathrm{H}$-glutamate binding sites were found in the septohippocampal nucleus, ventral lateral septum, and distinct subfields of the intermediate lateral septum, and lower levels were seen in the dorsal lateral septum.

Similar to the distribution of ${ }^{3} \mathrm{H}$-CPP binding sites in the septum, NR2A mRNA is in relatively low abundance in this region, with higher levels found in the dorsal lateral septum. In contrast to ${ }^{3} \mathrm{H}-\mathrm{CPP}$ binding sites and NR2A mRNA, NR2B mRNA was relatively abundant in the septum with higher densities found in the septohippocampal nucleus, ventral lateral septum, and distinct subfields of the intermediate lateral septum than in the dorsal lateral septum. NR1 + mRNA was present in low levels throughout the septum (Figs. $2 C, 3$ ) with even lower levels in the dorsal lateral septum. High levels of NR1mRNA were found throughout the lateral septum (Figs. 2D, 3), with higher levels in the dorsal lateral septum. Overall, the septal distribution of antagonist-preferring and agonist-preferring NMDA receptors most closely paralleled the distribution of NR2A and NR2B mRNA, respectively, and only partially paralleled the distribution of NR1 + and NR1 - mRNA, respectively.

Thalamic nuclei. Among the various nuclei of the thalamus, the same distinctive distribution was seen for both antagonist- 

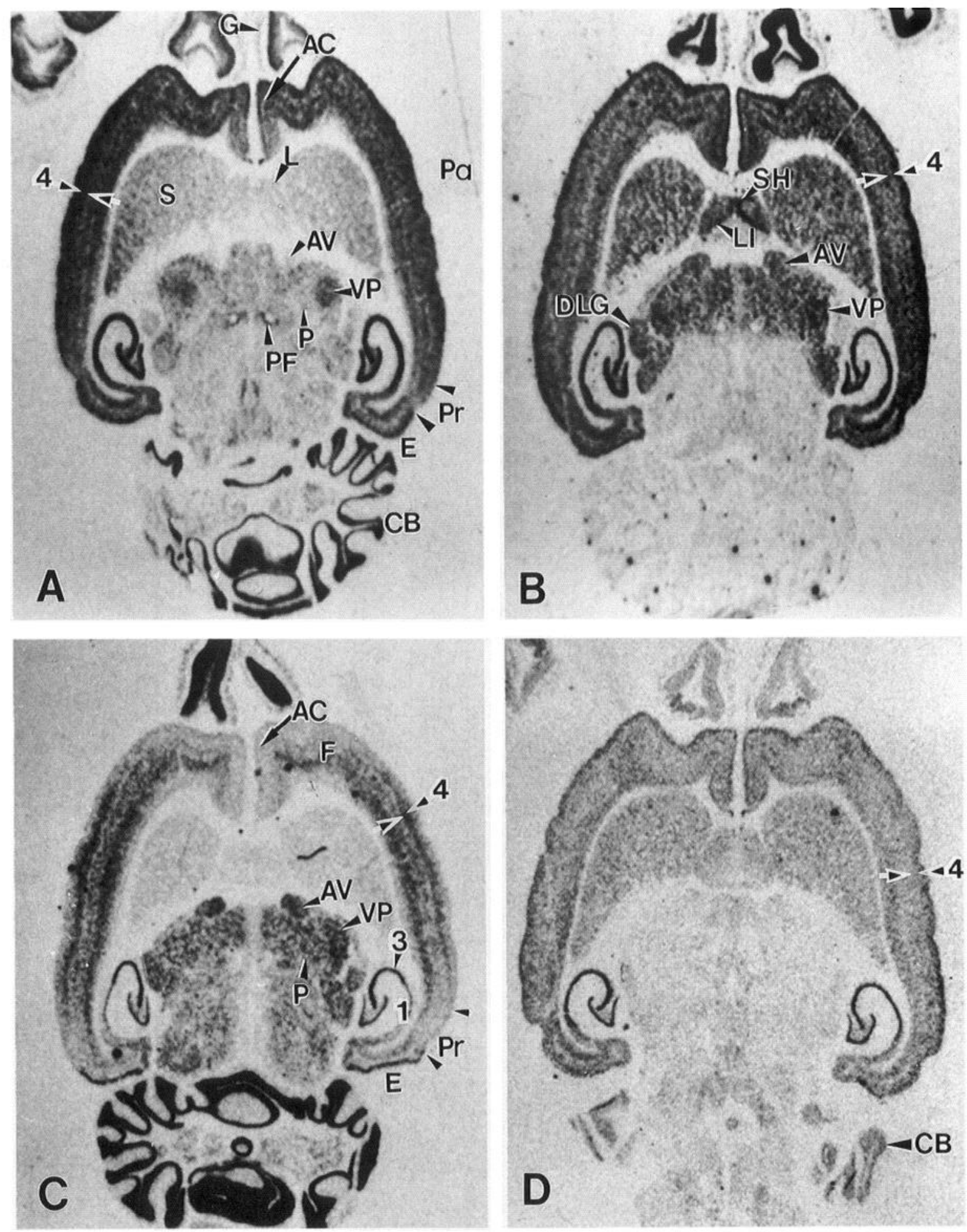

Figure 2. Localization of NR2 and NR1 subunit mRNAs by in situ hybridization: autoradiograms of in situ hybridization using ${ }^{35}$ S-labeled antisense oligonucleotide probes specific for NR2A $(A)$, NR2B $(B), \mathrm{NR} 1+(C)$, and NR1 $-(D)$. NR2A and NR1 + mRNA expression was low in the striatum $(S)$ and lateral septum $(L)$, perirhinal cortex $(P r)$, and anterior cingulate $(A C)$, and high in the ventroposterior nucleus $(V P)$, parietal cortex $(P a)$, layer $4(4)$, and superficial entorhinal cortex $(E)$. NR1 + mRNA expression differed from NR2A and antagonist-preferring sites by having high levels in the anteroventral nucleus $(A V)$ and low levels in CA1 hippocampus (1). 3, CA3 of hippocampus; $C B$, cerebellum; $E P$, external plexiform layer of the olfactory bulb; $F$, frontal/orbital cortex; $P$, posterior nucleus; $S H$, septohippocampal nucleus. Films were exposed for $21 \mathrm{~d}$ (NR2A, NR2B, NR1+) or $13 \mathrm{~d}(\mathrm{NR} 1-)$.

preferring NMDA receptors and NR2A mRNA (Figs. $1 A, 2 A$ ). High-affinity ${ }^{3} \mathrm{H}-\mathrm{CPP}$ binding sites and NR2A mRNA were found in highest concentrations in the ventral posterior nucleus, with high levels in the laterodorsal and mediodorsal lateral nu- clei and in the dorsal lateral geniculate. Moderate levels of ${ }^{3} \mathrm{H}$ CPP binding sites and NR2A mRNA were observed in the medial geniculate and paratenial nucleus, lower levels in the posterior and lateroposterior nuclei, and lowest levels in the 
[3H]CPP Binding Sites

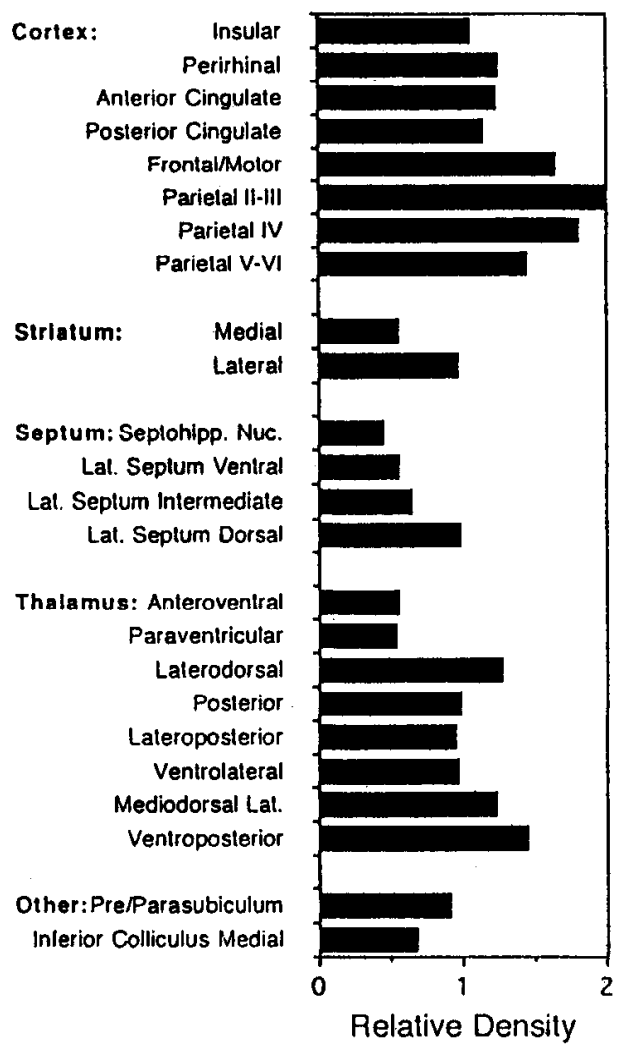

L-[3H]Glu Binding Sites

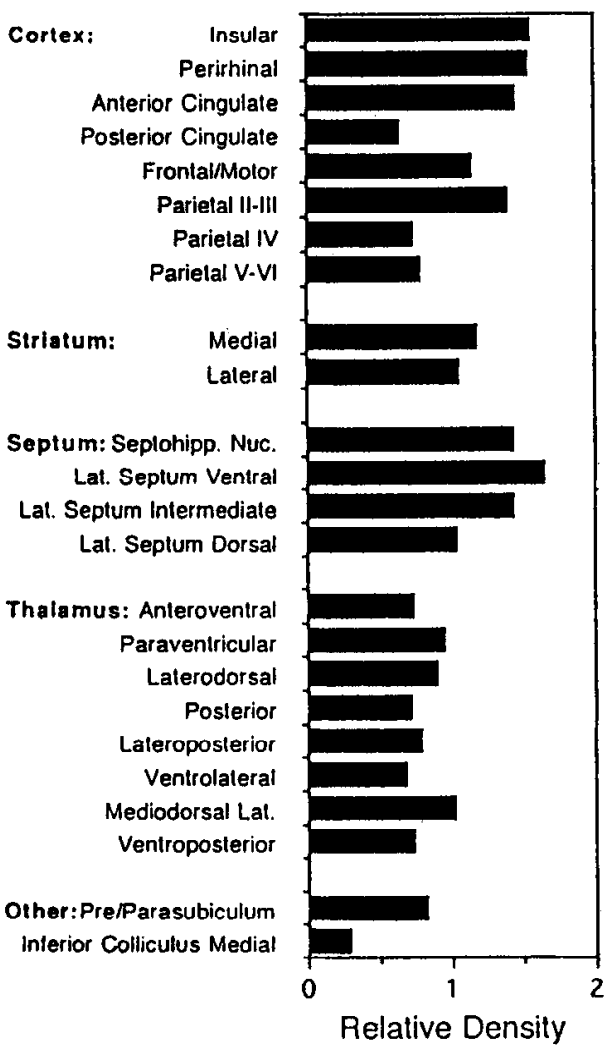

NR2A MRNA

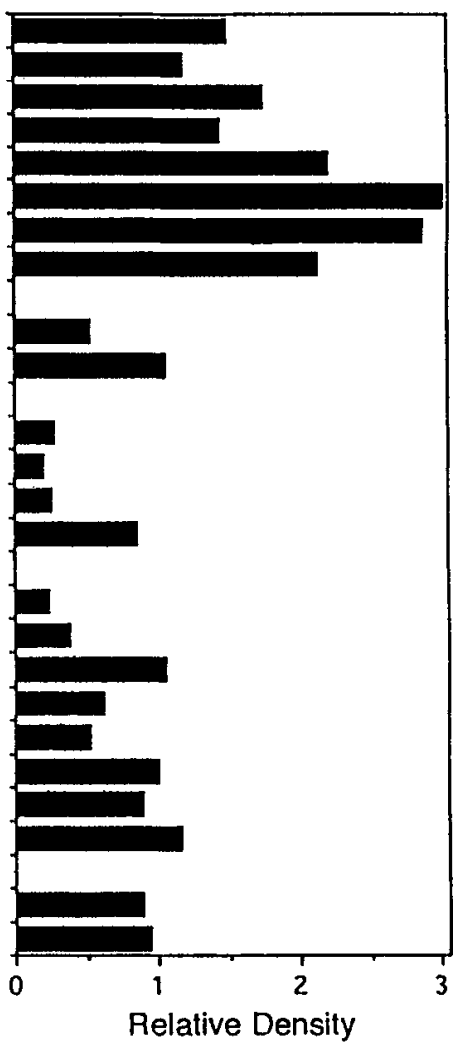

NR2B mRNA

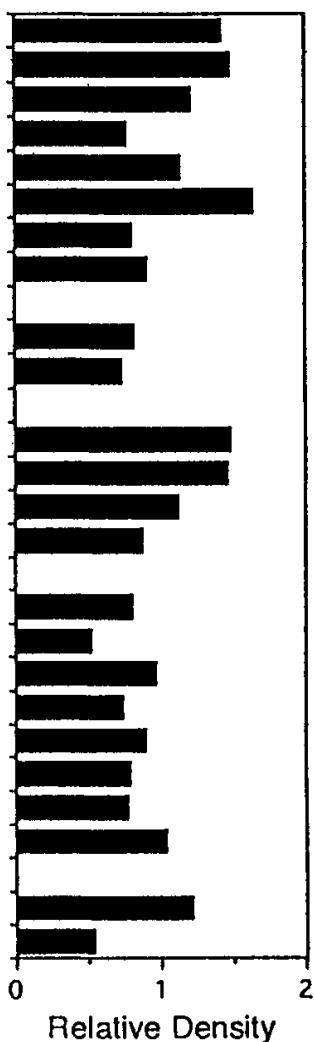

NR1+ mRNA

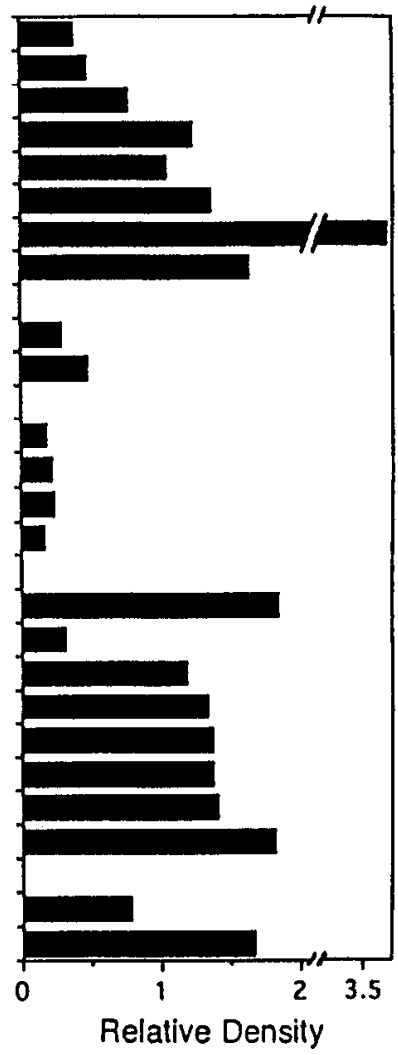

NR1- MRNA

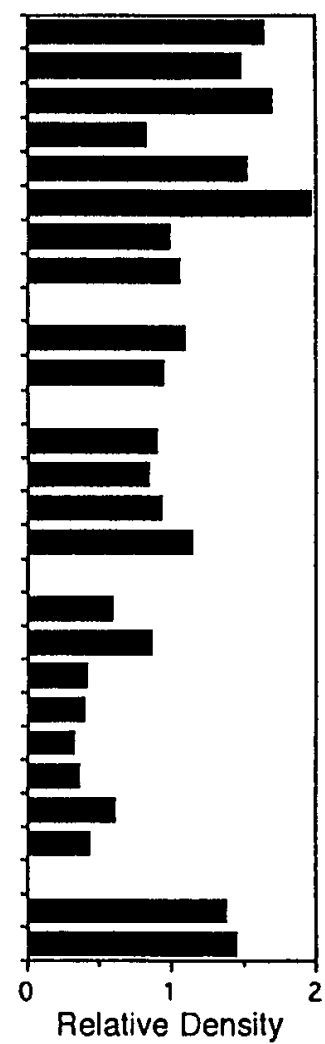

Figure 3. Quantitative comparison between the density of binding sites for ${ }^{3} \mathrm{H}-\mathrm{CPP}$ and L- ${ }^{3} \mathrm{H}$-glutamate and NMDA receptor subunit mRNA in representative brain regions. ${ }^{3} \mathrm{H}-\mathrm{CPP}$ binding density displayed a regional variation similar to that of NR2A mRNA and only partially similar to 
paraventricular and anteroventral nuclei (Figs. 1 $A, 2 A$ ). In addition, a high density of both NR2A mRNA and ${ }^{3} \mathrm{H}-\mathrm{CPP}$ binding sites was evident within the parafascicular nucleus in a band immediately surrounding the fasciculus retroflexus. NR2B mRNA was present at uniformly high levels throughout most of the thalamus, with lower levels in the paraventricular and intermediodorsal nuclei (Fig. 2B). The distribution of NR2B mRNA was distinct from that of antagonist-preferring receptors and NR2A mRNA, in that NR2B mRNA was found at high levels in the anteroventral nucleus and posterior nucleus and at low levels throughout the parafascicular nucleus.

The thalamic distribution of agonist-preferring NMDA receptors was difficult to determine due to the presence of a pharmacologically distinct NMDA receptor subtype that is present in several of the midline thalamic nuclei (Beaton et al., 1992; see also Fig. 5). Like agonist-preferring NMDA receptor binding sites, these binding sites also display higher affinity for $\mathrm{L}-{ }^{3} \mathrm{H}$ glutamate. Thus, the relatively high levels of $\mathrm{L}-{ }^{3} \mathrm{H}$-glutamate binding in the various midline thalamic nuclei (e.g., paraventricular and intermediodorsal nuclei) and in the medial geniculate and anteroventral nuclei are largely due to the presence of a distinct NMDA receptor subtype that displays a unique pharmacological profile (Beaton et al., 1992). Exclusion of regions displaying pharmacological properties characteristic of the midline thalamic nuclei (MT-like subtype) revealed that agonistpreferring NMDA receptors were expressed at a relatively low density throughout most of the thalamus (Fig. 1B). Agonistpreferring NMDA receptors defined as NMDA-specific $\mathrm{L}^{-3} \mathrm{H}$ glutamate binding in the presence of $6 \mu \mathrm{M} \mathrm{D}-\mathrm{AP} 5$ displayed lower relative density levels in lateral thalamic nuclei than NMDAspecific $\mathrm{L}^{-}{ }^{3} \mathrm{H}$-glutamate binding, consistent with our previous findings (Monaghan et al., 1988).

NR1 - mRNA was present at low levels throughout the thalamus (Figs. 2D, 3), while NR2B mRNA was found at high levels throughout most of the thalamus (Fig. $2 B$ ). Slightly higher levels of NR1 - mRNA were observed in nuclei found along the midline (paraventricular and intermediodorsal nuclei), while high levels of NR1 + mRNA (Fig. 2C) were expressed throughout the thalamus except for the midline structures (paraventricular and intermediodorsal nuclei). Among the thalamic nuclei, the anteroventral nucleus expressed the highest levels of NR1+ mRNA (and a low density of ${ }^{3} \mathrm{H}-\mathrm{CPP}$ binding sites and NR2A mRNA).

In summary, the thalamic organization of antagonist-preferring NMDA receptors closely paralleled the distribution of NR2A mRNA and was distinct from NR2B, NR1 + , and NR $1-$ mRNA distributions. The low levels of agonist-preferring NMDA receptors in the thalamus correlates with low levels of NR1mRNA and is distinct from the high thalamic levels of NR2A, NR2B, and NR1 + mRNAs.

Summary and correlational analysis of anatomical observations. Overall, there is a marked anatomical correspondence between NR2A mRNA and the expression of antagonist-preferring. NMDA receptors. Every brain region that expresses NR2A mRNA also expresses antagonist-preferring NMDA re-

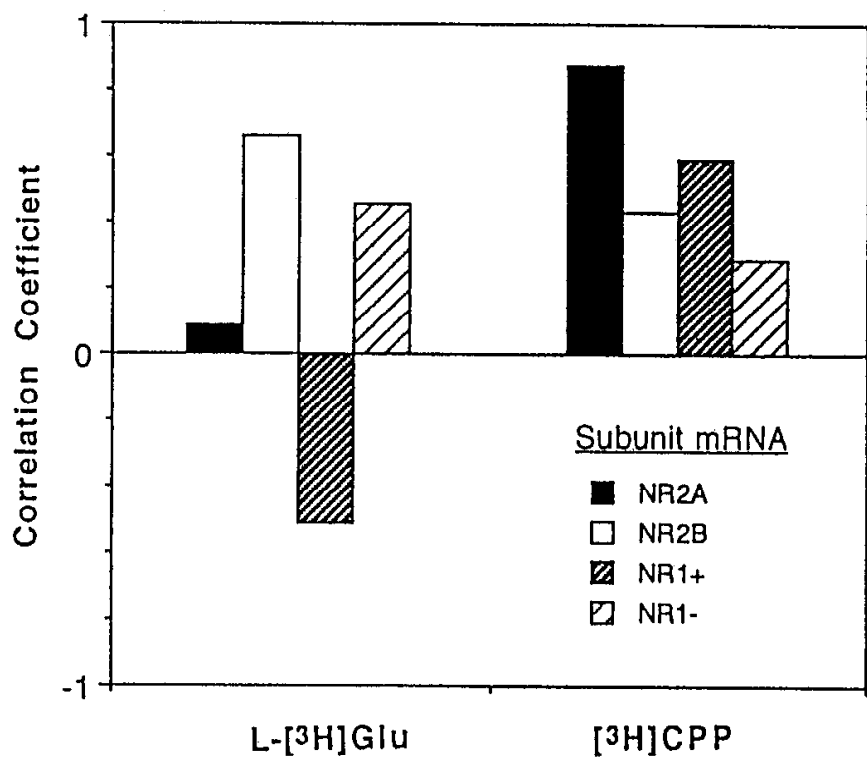

Figure 4. Correlational analysis between NMDA receptor binding sites and NMDA receptor subunit mRNA. Radioligand-receptor binding and $\mathrm{mRNA}$ density were determined in 32 brain regions (see Materials and Methods). These values were used to determine the correlation between $\mathrm{L}^{-3} \mathrm{H}$-glutamate or ${ }^{3} \mathrm{H}$-CPP binding sites and NMDA receptor subunit mRNA. For comparison, the correlation coefficient for $\mathrm{L}^{3} \mathrm{H}-$ glutamate and ${ }^{3} \mathrm{H}-\mathrm{CPP}$ binding sites was 0.09 , while the correlation coefficient for NR2A mRNA and NR2B mRNA was 0.45 .

ceptors. Convcrscly, the presence of antagonist-preferring sites is associated with NR2A expression. Quantitative analysis reveals that the density of NR2A mRNA and antagonist-preferring binding sites show a strong positive correlation $(r=0.88$; Fig. 4). The weak correlation between NR2B and antagonistpreferring site distributions $(r=0.44)$ is similar to the correlation between NR2A and NR2B mRNA distributions $(r=0.45)$.

The distribution of agonist-preferring NMDA receptors displays many similarities to the distribution of both NR2B and NR1 - mRNAs (each had similar cortical and striatal distributions and generally low levels in midbrain and brainstem). Overall, regions that display a low density of either NR2B or NR1 - mRNAs, also have a low density of agonist-preferring sites. Thus, low levels of agonist-preferring sites were found in the lateral thalamic nuclei (including ventral posterior, posterior, and dorsal lateral geniculate) where there is a low density of NR1 - inscrt 1 mRNA but high NR2B mRNA levels (Figs. 1, 2). Conversely, in the hypothalamus, low levels of agonist-preferring receptors correlates with low levels of NR2B mRNA and not the higher levels of NR1 - mRNA (data not shown). Similarly, in the lateral septum, the distribution of agonist-preferring sites corresponds better to the distribution of NR2B, rather than NR1 -, mRNA (Fig. 3). Correlation coefficient analysis (Fig. 4) indicates that agonist-preferring NMDA receptors exhibit a moderate positive correlation to NR $1-$ mRNA $(r=0.46)$, a better correlation to NR2B mRNA ( $r=0.67)$, and a negative correlation to NR $1+\operatorname{mRNA}(r=-0.51)$.

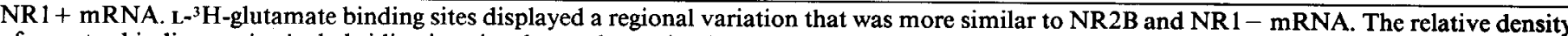

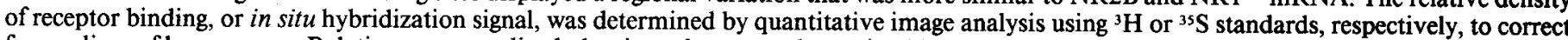

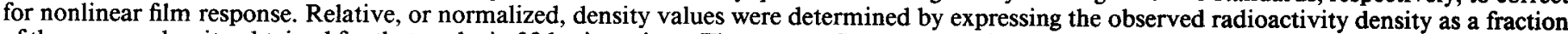

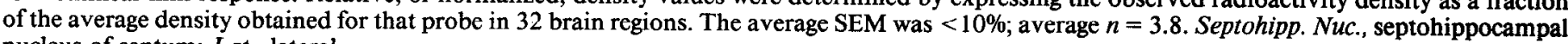
nucleus of septum; Lat., lateral. 

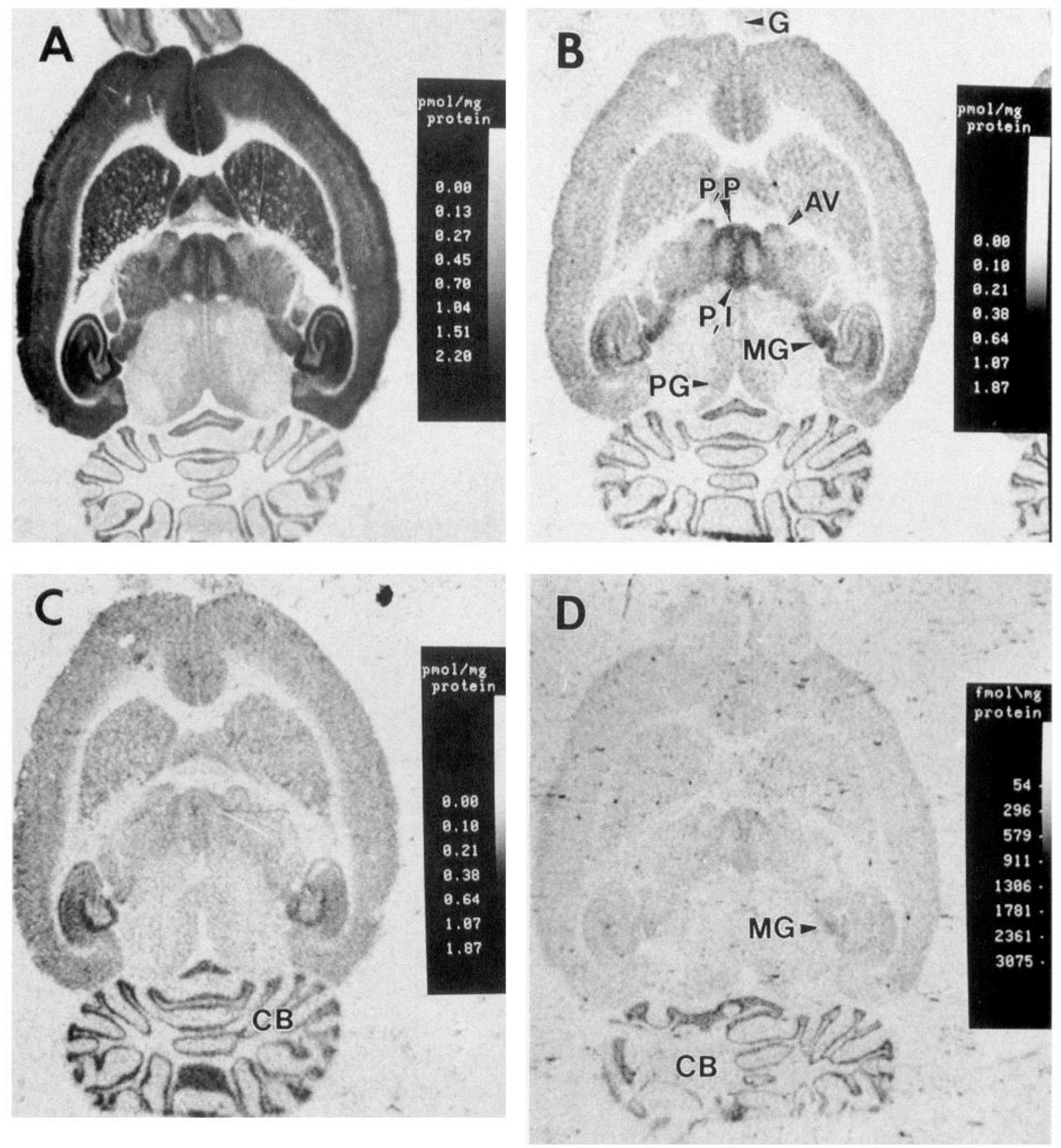

Figure 5. Distribution of pharmacologically distinct NMDA receptor binding sites. In the absence of inhibitors $(A)$ L- ${ }^{3} \mathrm{H}-$ glutamate binding sites are found throughout the brain. Addition of $16 \mu \mathrm{M}$ homoquinolinate $(B), 50 \mu \mathrm{M}$ LY233536 (C), and $10 \mu \mathrm{M}$ D-CPPene $(D)$ inhibits L- ${ }^{3} \mathrm{H}-\mathrm{glutamate}$ binding in select brain regions. Homoquinolinate potently inhibited binding in all regions except the midline thalamic nuclei $(P, P$, paratenial and paraventricular-anterior nuclei; $P, I$, paraventricular-posterior and intermediodorsal nuclei), anteroventral nucleus $(A V)$, the cerebellum $(C B)$, the olfactory bulb glomerular layer $(G)$, periaqueductal gray $(P G)$, and the medial geniculate $(M G)$. In contrast, LY233536 $(C)$ potently inhibited binding in all regions except the cerebellum. At relatively high concentrations $(10 \mu \mathrm{M}) \mathrm{D}-\mathrm{CPPene}(D)$ potently inhibited $\mathrm{L}-{ }^{3} \mathrm{H}-\mathrm{glutamate}$ binding in all regions except the cerebellum.

\section{Localization of pharmacologically atypical NMDA receptors and comparison to NR2C and NR2D mRNA distributions}

Receptor-radioligand binding studies. Previous studies have shown that NMDA receptor binding sites in the cerebellum (Ebert et al., 1991; Monaghan and Beaton, 1991; Yoneda et al., 1991; Beaton et al., 1992) and in various midline thalamic nuclei (Beaton et al., 1992) display distinct pharmacological properties. In order to isolate these two NMDA receptor subtypes phar- macologically, a variety of agonists and antagonists were screened for greater subtype specificity. Evaluation of approximately $\mathbf{4 0}$ compounds (data not shown) revealed that two showed greater selectivity between brain regions: the agonist homoquinolinate (HQ) and the antagonist D-3-(2-carboxypiperazin-4-yl)-1-propenyl-1-phosphonic acid (D-CPPene). As shown in Figure 5, D-CPPene and HQ were potent inhibitors of $\mathrm{L}^{-}{ }^{3} \mathrm{H}$-glutamate binding to NMDA receptors in the forebrain and poor inhibitors of binding in the cerebellum and midline thalamus, a pattern 

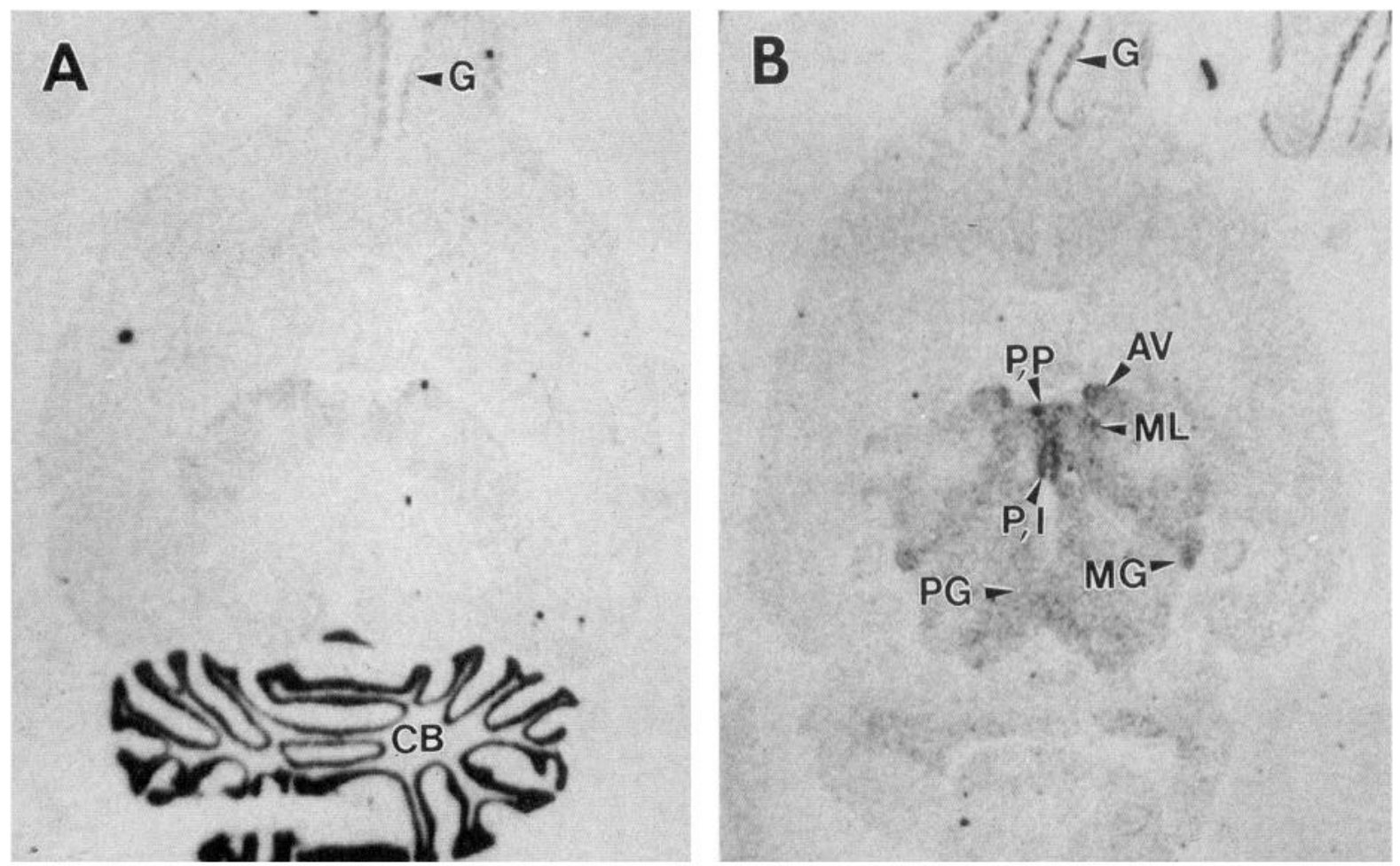

Figure 6. Distribution of NR2C $(A)$ and NR2D $(B)$ mRNA. NR2C mRNA was found predominantly in the cerebellum $(C B)$; low levels were also found in the olfactory bulb glomerular layer $(G)$; and very low levels were found in the thalamus. NR2D mRNA was restricted to the olfactory bulb glomerular layer and to various diencephalic nuclei $(P, P$, paratenial and paraventricular-anterior nuclei; $A V$, anteroventral nucleus; $M L$, mediodorsal lateral nucleus; $P, I$, paraventricular-posterior and intermediodorsal nuclei; $M G$, medial geniculate; $P G$, periaqueductal gray). Autoradiograms were exposed for $21 \mathrm{~d}(\mathrm{NR} 2 \mathrm{C})$ or $41 \mathrm{~d}$ (NR2D).

identical to that previously described for CPP (Beaton et al., 1992). At relatively high concentrations (30 times the average forebrain $K_{i}$ ), D-CPPene (data not shown) and HQ (Fig. $5 B$ ) weakly inhibited $\mathrm{L}^{-3} \mathrm{H}$-glutamate binding in the midline thalamic nuclei and cerebellar granule cell layer, although binding in most other brain regions was almost completely inhibited. At even higher concentrations (60 times the average forebrain $K_{i}$ ), D-CPPene (Fig. 5D) and HQ (data not shown) still weakly inhibited $\mathrm{L}^{-}{ }^{3} \mathrm{H}$-glutamate binding in the cerebellar granule cell layer. While the midline thalamic nuclei and the cerebellum both display a lower affinity for HQ, D-CPPene, and CPP, NMDA receptors in these regions are differentially sensitive to the antagonist LY233536 (Beaton et al., 1992; presented in Fig. 5 for comparison). LY233536, at a concentration that was 13 times the average forebrain $K_{i}$, potently inhibited NMDA-sensitive $\mathrm{L}^{-3} \mathrm{H}$-glutamate binding in the midline thalamic nuclei but not in the cerebellum (Fig. $5 C$ ).

The anatomical distributions of NMDA receptors that have the pharmacological properties of the midline thalamus (MTlike) and the cerebellum (cerebellar-like) were further evaluated. The distribution of NMDA-sensitive $\mathrm{L}-{ }^{3} \mathrm{H}$-glutamate binding sites, which were poorly displaced by $10 \mu \mathrm{M}$ CPP and $10 \mu \mathrm{M}$ D-CPPene and potently inhibited by $20 \mu \mathrm{M}$ and $50 \mu \mathrm{M} \mathrm{LY} 233536$ (MT-like pharmacology), was determined. In addition to the paraventricular and intermediodorsal nuclei, MT-like NMDA receptors were found in the anteroventral nucleus, the medial geniculate, the mediodorsal lateral nucleus, and the periaqueductal gray (compare Fig. $5 B, C$ ). In other planes of section (data not shown) NMDA receptors of similar pharmacology were found in the rhomboid nucleus, the nucleus of the diagonal band, and the interpeduncular nucleus. Examination of 10 animals in several levels of coronal, parasagittal, and horizontal planes did not reveal any NMDA receptors with pharmacological properties similar to the cerebellum. NMDA receptors of the glomerular layer of the olfactory bulb were found have a low affinity for HQ and D-CPPene, but specificity for LY233536 was inconclusive (thus it is uncertain if the glomerular NMDA receptors are cerebellar-like or MT-like).

Distribution of NR2C and NR2D subunit mRNA. In situ hybridization was performed to compare the distribution of NR2 subunit mRNAs to that of the pharmacologically atypical NMDA receptors found in the cerebellum and midline thalamus (Fig. 6). As previously described, NR2C mRNA is almost exclusively localized to the cerebellum (Kutsuwada et al., 1992; Monyer et al., 1992; Ishii et al., 1993; Fig. 6A). In addition, NR2C mRNA was found at lower concentrations in the pineal gland while NMDA-sensitive $\mathrm{L}^{-}{ }^{3} \mathrm{H}$-glutamate binding sites were not found in the pineal.

NR2D mRNA was found throughout the diencephalon and midbrain (in agreement with Ishii et al., 1993; Fig. 6B). Regions containing the highest levels of NR2D mRNA were identified as the paratenial nucleus, paraventricular nucleus, intermediodorsal nucleus, mediodorsal lateral nucleus, anteroventral nucleus, medial geniculate, and rhombiod nucleus (Fig. $6 B$ ). Significant levels of NR2D mRNA were also found in the periaqueductal gray (especially the dorsal subdivision), interpeduncular nucleus, the glomerular layer of the olfactory bulb, and the nucleus of the diagonal band. In the adult rat brain, the telencephalon contained very low levels, except the dentate gyrus, which had low levels. Overall, the distribution pattern of 

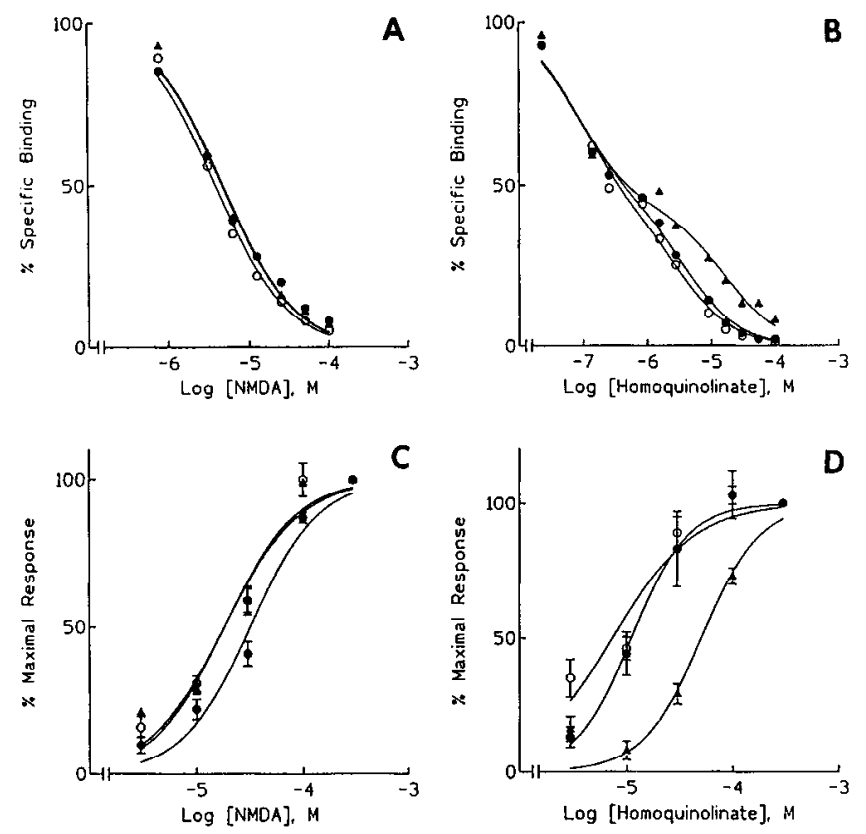

Figure 7. Comparison of inhibition of $\mathrm{L}-{ }^{-3} \mathrm{H}$-glutamate binding by agonists $(A, B)$ in lateral thalamus (solid circles), medial striatum (open circles), and cerebellar granule cell layer (solid triangles) and agonist activation (plus $10 \mu \mathrm{M}$ glycine) of receptor complexes in Xenopus oocytes $(C, D)$; NR1/NR2A (solid circles), NR1/NR2B (open circles), and NR1/ NR2C (solid triangles). Dose-response curves were generated for agonist competitors (NMDA and $\mathrm{HQ}$ ) of $\mathrm{L}-{ }^{3} \mathrm{H}$-glutamate binding $(A, B)$ by computer-assisted image analysis of autoradiograms. Dose-response curves for agonist activation of heteromeric NMDA receptor complexes $(C, D)$ expressed in oocytes were fit according to the equation $I=I_{\max } /$ $\left[1+\left(\mathrm{EC}_{\mathrm{so}} / A\right)^{n}\right]$, as described in Materials and Methods. Each point represents the mean \pm SEM of three to six oocytes taken from the same frog.
NR2D subunit distribution was indistinguishable from that of NMDA receptors, which have a high affinity for LY233536 and a low affinity for HQ, CPP, and D-CPPene (compare Fig. 5, $B$ minus $C$, to Fig. $6 B$ ).

\section{Pharmacology of native and recombinant NMDA receptors}

Colocalization of specific NR2 subunit mRNAs and distinct NMDA receptor populations suggested that the NR2 subunit contributes to the distinct pharmacologies of NMDA receptor subtypes. To test this hypothesis, the pharmacological profiles of NMDA receptors were determined in brain regions that contain relatively pure populations of NMDA receptor subtypes and subunits. Thus, the pharmacological properties of the lateral thalamus (enriched in NR2A mRNA and antagonist-preferring receptors), the medial striatum (which displays the purest population of both NR2B mRNA and agonist-preferring receptors), and the cerebellar granule cell layer (containing NR2C mRNA) were compared to the pharmacology of three heteromeric NMDA receptors expressed in Xenopus oocytes: NR1/NR2A, NR1/R2B, and NR1/NR2C.

The qualitative results shown in Figure $5 B$ indicate that $\mathrm{HQ}$ displays a low affinity for inhibiting $\mathrm{L}_{-}{ }^{3} \mathrm{H}$-glutamate binding to cerebellar NMDA receptors. Quantitative analysis of $\mathrm{HQ}$ inhibition of $\mathrm{L}-{ }^{3} \mathrm{H}$-glutamate binding to NMDA receptors (Fig. 7; see also Table 1) revealed that the weak potency of HQ for cerebellar NMDA receptors labelled by L- ${ }^{3} \mathrm{H}$-glutamate was due to a low-affinity HQ binding site unique to the cerebellum. In each of the three brain regions examined, HQ inhibition curves could be resolved into two components with approximately equal proportions of high and low affinity binding sites (see Table 1). While the high-affinity binding components in the lateral thalamus, medial striatum, and cerebellum had similar $K_{i}$ values $\left(K_{i}=0.1,0.2\right.$, and $0.3 \mu \mathrm{M}$, respectively), the low-affinity

Table 1. Agonist and antagonist potencies against recombinant NMDA receptors expressed in Xenopus oocytes and $\mathrm{L}-{ }^{-3} \mathrm{H}-\mathrm{glutamate}$ binding to native NMDA receptors in brain

Quantitative autoradiography: average $k_{i}(\mu \mathrm{M}) \pm \mathrm{SEM}$
Xenopus oocytes:

$\mathrm{EC}_{50}$ or $\mathrm{IC}_{50}(\mu \mathrm{M}) \pm \mathrm{SEM}$

\begin{tabular}{|c|c|c|c|c|}
\hline $\begin{array}{l}\text { Affinity } \\
\text { ratio }\end{array}$ & & & & $\begin{array}{l}\text { Affinity } \\
\text { ratio }\end{array}$ \\
\hline $\begin{array}{l}\text { LTII: } \\
\text { MS }\end{array}$ & $\begin{array}{l}\text { NR1/ } \\
\text { NR2A }\end{array}$ & $\begin{array}{l}\text { NR1/ } \\
\text { NR2B }\end{array}$ & $\begin{array}{l}\text { NR1/ } \\
\text { NR2C }\end{array}$ & $\begin{array}{ll}\text { NR2A: } & \text { NR2C: } \\
\text { NR2B } & \text { NR2B }\end{array}$ \\
\hline
\end{tabular}

\begin{tabular}{|c|c|c|c|}
\hline \multicolumn{4}{|l|}{ Agonists } \\
\hline NMDA & $3.9 \pm 0.22$ & $2.8 \pm 0.14$ & $4.10 \pm$ \\
\hline \multirow[t]{2}{*}{ Homoquinolinate ${ }^{a}$} & $\begin{array}{l}0.1 \pm 0.09 \\
(54 \%)\end{array}$ & $\begin{array}{l}0.2 \pm 0.1^{*} \\
(55 \%)\end{array}$ & $\begin{array}{c}0.3 \pm \\
(50 \%)\end{array}$ \\
\hline & $\begin{array}{l}5.1 \pm 3.14 \\
(46 \%)\end{array}$ & $\begin{array}{l}3.3 \pm 0.67 \\
(45 \%)\end{array}$ & $\begin{array}{c}58 \pm \\
(50 \%)\end{array}$ \\
\hline \multicolumn{4}{|l|}{ Antagonists } \\
\hline D-AP5 & $3.1 \pm 0.31$ & $8.1 \pm 0.6^{*}$ & $16 \pm$ \\
\hline D-CPPene ${ }^{a}$ & $0.12 \pm 0.02 \ddagger$ & $0.19 \pm 0.03$ & $\begin{array}{l}0.25 \pm \\
(48 \%) \\
14.3 \pm \\
(52 \%)\end{array}$ \\
\hline $\begin{array}{l}\text { "Statistical analysis anc } \\
\text { * Significantly different } \\
\text { † Significantly different } \\
\text { † Significantly different } \\
\text { § Significantly different } \\
\text { \# Significantly different }\end{array}$ & $\begin{array}{l}\text { finity ratio de } \\
\text { m LTH, } p< \\
\text { m MS, } p<0 \\
\text { m MS, } p<0 \\
\text { m NR1/NR2 } \\
\text { m NR1/NR2 }\end{array}$ & $\begin{array}{l}\text { (Scheffe } F \text { t } \\
\text { Scheffe } F \text { tes } \\
\text { Fisher PLSL } \\
<0.05 \text { (Sch } \\
<0.05 \text { (Sch }\end{array}$ & st). \\
\hline
\end{tabular}


component observed in the cerebellum $\left(K_{i}=58 \mu \mathrm{M}\right)$ differed significantly from the low-affinity component observed in the lateral thalamus $(5.1 \mu \mathrm{M})$ and medial striatum $(3.3 \mu \mathrm{M}$; see Table 1).

Selective effects of HQ were also observed in Xenopus oocytes expressing heteromeric NR1-NR2 complexes. Relative to NR2A- and NR2B-containing receptor heteromers, NR1/NR2C receptors showed significantly lower affinity for HQ (Fig. 7, Table 1). Interestingly, although HQ was an agonist at all heteromeric recombinant NMDA receptors expressed in Xenopus oocytes, it was less efficacious than NMDA at the NR1/NR2C receptor (data not shown). The Hill coefficients for HQ activation of oocyte expressed NMDA receptors were $1.9 \pm 0.3$ (NR1/NR2A), $1.1 \pm 0.1(\mathrm{NR} 1 / \mathrm{NR} 2 \mathrm{~B})$, and $1.6 \pm 0.2(\mathrm{NR} 1 /$ NR2C).

In contrast to the relatively selective actions of HQ, NMDA did not discriminate between forebrain and cerebellar NMDA receptors labeled by L ${ }^{-}{ }^{3} \mathrm{H}$-glutamate (Fig. 7). Likewise, NMDA potency at the NR1/NR2C complex was not markedly different from NMDA potency at NR 1/NR2A or NR1/NR2B receptors. However, HQ and NMDA did display small but consistently higher affinities at medial striatal NMDA receptors than at lateral thalamic NMDA receptors. These differences were also observed in oocytes expressing heteromeric NMDA receptors; HQ and NMDA displayed higher potencies at NR 1/NR2B receptors as compared to NR 1/NR2A receptors. The Hill coefficients for NMDA activation of oocyte-expressed NMDA receptors were $1.3 \pm 0.1(\mathrm{NR} 1 / \mathrm{NR} 2 \mathrm{~A}), 1.3 \pm 0.1(\mathrm{NR} 1 / \mathrm{NR} 2 \mathrm{~B})$, and $1.2 \pm$ 0.1 (NR1/NR2C).

Quantitative analysis of antagonist inhibition of $\mathrm{L}^{-3} \mathrm{H}$-glutamate binding to native NMDA receptor subtypes in lateral thalamus, medial striatum, and cerebellum is shown in Figure 8. NMDA receptors in the lateral thalamus had the highest affinities for all antagonists tested, while receptors in the cerebellum had the lowest antagonist affinities. Compared to D- AP5, $\mathrm{D}$-CPPene displayed a greater selectivity between forebrain and cerebellar NMDA receptors. D-CPPene more potently inhibited forebrain NMDA receptors as compared to cerebellar receptors (see Table 1). As was observed for HQ, D-CPPene inhibition of $\mathrm{L}^{-3} \mathrm{H}$-glutamate binding in the cerebellum was best fit by a twosite model with $53 \%$ of the binding sites having a low affinity for D-CPPene (see Table 1). D- CPPene also displayed greater selectivity than D-AP5 for the inhibition of heteromeric NMDA receptor complexes expressed in Xenopus oocytes (Fig. 8C,D). D-CPPene more potently inhibited NR1-NR2A and NR1-NR2B heteromers as compared to NR1-NR2C receptors. The oocyteexpressed NR 1-NR2A receptor was most sensitive to inhibition by D-AP5 and D- CPPene, while the NR 1-NR2C receptor was the least sensitive.

\section{Discussion}

Relationship between NMDA receptor subunits and agonistpreferring/antagonist-preferring NMDA receptor subtypes

Four distinct populations of NMDA receptors have been described by radioligand binding and electrophysiological assays: (1) agonist-preferring and (2) antagonist-preferring NMDA receptors (Monaghan et al., 1988; Honoré et al., 1989; Monaghan, 1991; Sakurai et al., 1993), (3) cerebellar NMDA receptors with distinctive pharmacological properties (Perkins and Stone, 1983; Sekiguchi et al., 1990; Ebert et al., 1991; Monaghan and Beaton, 1991; O'Shea et al., 1991; Yoneda and Ogita, 1991; Beaton et al., 1992), and (4) midline thalamus (MT-like) NMDA receptors
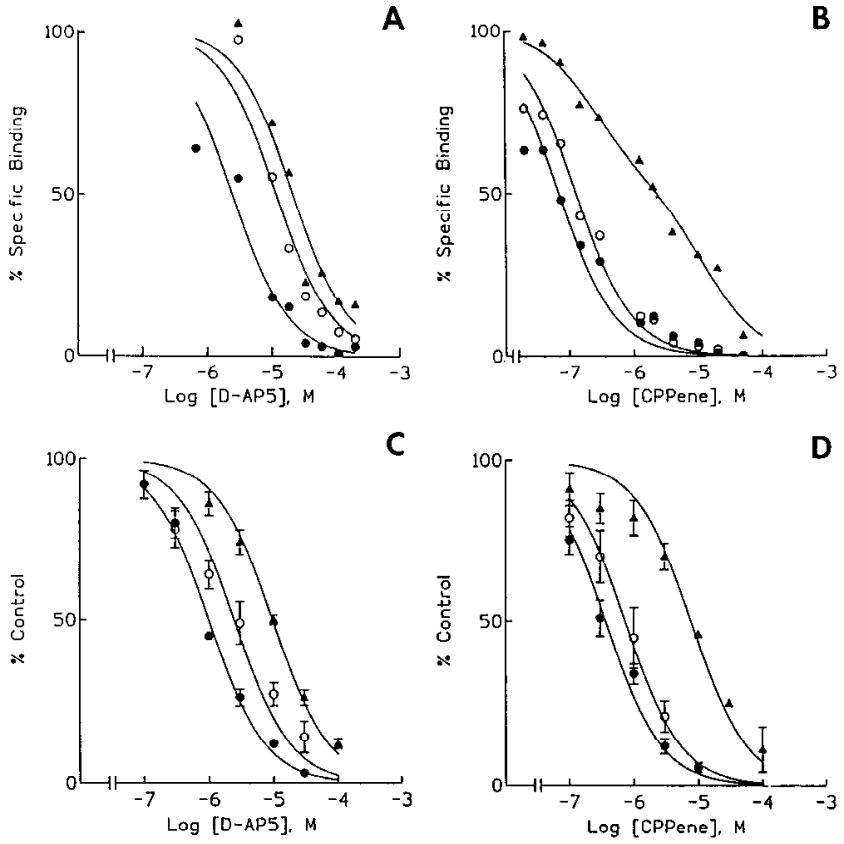

Figure 8. Comparison of inhibition of $\mathrm{L}^{-3} \mathrm{H}$-glutamate binding by antagonists $(A, B)$ in lateral thalamus (solid circles), medial striatum (open circles), and cerebellar granule cell layer (solid triangles) and antagonist inhibition of heteromeric receptor complexes in Xenopus oocytes $(C$, D); NR1-NR2A (solid circles), NR1-NR2B (open circles), and NR1NR2C (solid triangles). Antagonist inhibition curves for D-AP5 $(A)$ and D-CPPene $(B)$ inhibition of $\mathrm{L}^{-3} \mathrm{H}$-glutamate binding were generated by computer-assisted image analysis of autoradiograms. Inhibition curves for antagonist inhibition of currents elicited by $100 \mu \mathrm{M}$ NMDA, in the presence of $10 \mu \mathrm{M}$ glycine, in oocytes expressing heteromeric NMDA receptor complexes were fit according to the equation $I=I_{\max }-I_{\max } /$ $\left[1+\left(\mathrm{IC}_{50} / A\right)^{n}\right]$, and corrected for agonist affinity, as described in Materials and Methods. Each point represents the mean \pm SEM of three to six oocytes taken from the same frog.

with other, unique pharmacological properties (Beaton et al., 1992). The results of this report demonstrate that the anatomical distributions of each of the four subtypes show striking parallels to the distributions of individual NR2 subunit mRNAs and that the NR2 subunit is of critical importance in determining receptor subtype pharmacology.

The distribution of the antagonist-preferring subtype, as defined by high-affinity ${ }^{3} \mathrm{H}$-CPP binding, is virtually identical to the distribution of NR2A subunits. In all brain regions examined, the presence of NR2A mRNA predicted the presence of ${ }^{3} \mathrm{H}$-CPP binding sites. Conversely, all brain regions expressing antagonist-preferring NMDA receptors also expressed NR2A mRNA. Furthermore, there is a strong positive correlation $(r=$ 0.88 ) between the density of ${ }^{3} \mathrm{H}-\mathrm{CPP}$ binding sites and the density of NR2A subunit mRNA. No other subunit, or combination of subunits, displayed such a strong anatomical correspondence.

The high correlation between high-affinity ${ }^{3} \mathrm{H}$-CPP binding sites and NR2A mRNA suggests that ${ }^{3} \mathrm{H}-\mathrm{CPP}$ poorly labels NMDA receptors that do not have NR2A subunits. This hypothesis is consistent with the observation that radiolabeled antagonists do not label NMDA receptors in brain regions that contain high concentrations of NR2D subunits (e.g., olfactory bulb glomerular layer, anteroventral nucleus, paraventricular nucleus, intermediodorsal nucleus). Furthermore, HQ inhibits the binding of the antagonist ${ }^{3} \mathrm{H}$-CGP39653 in the cerebellum (which contains NR2A and NR2C mRNAs) with only a single 
high-affinity component (Monaghan and Beaton, unpublished observations), suggesting that ${ }^{3} \mathrm{H}-\mathrm{CGP} 39653$ binding in the cerebellum may be due to NR2A and not NR2C subunits. In the present study, ${ }^{3} \mathrm{H}-\mathrm{CPP}$ poorly labeled NMDA receptors in regions that contain predominantly NR2B mRNA (e.g., striatum and lateral septum); however, in other studies (Monaghan, Beaton, and Larson, unpublished observations) we have found that the antagonist ${ }^{3} \mathrm{H}$-CGP39653 binds with low affinity in regions containing NR2B mRNA (e.g., striatum, septum). Taken together, these findings suggest that the high-affinity antagonist binding site (Murphy et al., 1988; Porter et al., 1992; vanAmsterdam et al., 1992; Benke et al., 1993) represents NR2A-containing NMDA receptors while the low-affinity radiolabeled antagonist binding site represents NMDA receptors that contain NR2B subunits.

Based upon pharmacological experiments with recombinant receptors expressed in Xenopus oocytes, it has been proposed that the presence of the NR1 + subunit confers the antagonistpreferring NMDA receptor subtype properties and the NR1subunit is responsible for agonist-preferring subtype (Hollmann et al., 1993). The anatomical evidence presented in this report suggests that in many brain regions, high-affinity ${ }^{3} \mathrm{H}-\mathrm{CPP}$ binding sites are coexpressed with NR $1+$ mRNA $(r=0.59)$. For example both markers have similar patterns of cortical variation, and both are present in high levels in the thalamus and inferior colliculus and low levels in the striatum and septum. However, there are several differences in the distributions of ${ }^{3} \mathrm{H}$-CPP binding sites and NR $1+$ mRNA. For example, the anteroventral nucleus displays high levels of NR1 + mRNA and yet displays very low levels of ${ }^{3} \mathrm{H}$-CPP binding sites (and NR2A mRNA). Conversely, CA1 hippocampus has relatively high levels of ${ }^{3} \mathrm{H}-\mathrm{CPP}$ binding sites (and NR2A mRNA) and low levels of NR 1 + mRNA. Furthermore, the distinctive patterns of variation in ${ }^{3} \mathrm{H}-\mathrm{CPP}$ binding sites within the thalamus, septum, and cortical layers correspond well to NR2A subunit mRNA and not to NR1 + mRNA.

Agonist-preferring NMDA receptors (as defined by $\mathrm{L}^{3} \mathrm{H}$-glutamate binding that is weakly inhibited by D- AP5 and potently inhibited by HQ) are found predominately in the subset of brain regions that contain both $\mathrm{NR} 2 \mathrm{~B}$ and NR1 - mRNA. In many brain regions NR2B and NR1-insert 1 mRNA are colocalized $(r=0.59)$. For example, both subunit transcripts show the same detailed pattern of cortical variation and cortical lamination and are present in high levels in the striatum, septum, hippocampus, and dorsal medial infcrior colliculus, and in low levcls throughout most of the midbrain and brainstem. This pattern is similar to agonist-preferring NMDA receptors and dissimilar to other NMDA receptor subtypes.

In regions where there are low densities of either NR2B or NR1 - mRNA, there is a low density of agonist-preferring NMDA receptors as well. Overall, regions that have agonistpreferring NMDA receptors have significant levels of both NR2B and NR1- mRNA. Thus, these data suggest that agonist-preferring receptors may result from the combination of NR2B and NR1 - subunits. This would account for the low levels of agonist-preferring NMDA receptors in the thalamus and CA3 hippocampus (regions where NR $1+$ mRNA is expressed at high levels) and would account for the lower density of agonist-preferring binding sites in the dorsal lateral septum, brainstem, and cerebellum (regions where NR2B is expressed at low levels). Thus, by this hypothesis, when NR2B subunits form a complex with NR 1 - subunits, the resulting receptor has a high affinity for agonists. Conversely, receptor complexes containing NR $1+/$ NR2B subunits would display a reduced affinity for agonists. This hypothesis is consistent with recent findings that NMDA receptors composed of NRI + subunits display lower agonist affinity (Nakanishi et al., 1992; Durand et al., 1993; Hollmann et al., 1993) and higher antagonist affinity (Hollmann et al., 1993) than NR1 - receptors.

The anatomical distribution of subunit mRNAs suggests that NR2A subunits are associated with antagonist-preferring NMDA receptors. Thus, for a given NR1 subunit, NR2A subunits may confer higher antagonist affinity to the NR1-NR2 complex, whereas NR2B subunits may confer higher agonist affinity. Using the Xenopus oocyte expression system, we find that NR2Acontaining receptors consistently display a higher affinity for antagonists than the NR2B-containing receptor. In contrast, NR1/NR2B receptors have a higher affinity for agonists that was similar in magnitude to that reported for the mouse homolog to the NR2B subunit ( $\epsilon 2$ compared to $\epsilon 1$; Kutsuwada et al., 1992; Yamazaki et al., 1992) and similar in magnitude to that seen in radioligand binding studies for agonist-preferring NMDA receptors (compared to antagonist-preferring receptors). Thus, the anatomical and physiological evidence is consistent with the hypothesis that agonist-preferring and antagonist-preferring NMDA receptors are largely determined by NR2B and NR2A subunits.

Alternative splicing at the second and third NR 1 cassette sites (deletion 1 and deletion 2, Sugihari et al., 1991) are thought to have less of an effect upon NMDA receptor pharmacology, since homomeric receptors consisting of subunits alternatively spliced at the second or third cassettes do not have significant differences in NMDA receptor pharmacological properties (Nakanishi et al., 1992; Durand et al., 1993; Hollman et al., 1993). Consistent with these findings, we find that mRNAs alternatively spliced at the second and third cassettes have distribution patterns dissimilar to that of apparent NMDA receptor subtypes (Monaghan and Buller, 1994; Monaghan, Schneider, and Larson, unpublished observations). However, it will be important to determine if these alternatively spliced forms can alter the pharmacological properties of heteromeric receptor complexes.

\section{Relationship between NR2C/NR2D subunit $m R N A$ and cerebellar/MT-like $N M D A$ receptors}

NR2C subunits display an obvious anatomical correspondence to the pharmacologically atypical subtype of NMDA receptor found in the cerebellum. Since NR2C mRNA is the only known NMDA receptor subunit that has a distribution that can account for the unique pharmacology of the cerebellum, it is significant that coexpression of the NR2C mRNA with NR1 mRNA in oocytes results in a receptor complex that has pharmacological similarities to the native cerebellar receptor. Thus, both the anatomical and pharmacological data suggest that the NR2C subunit is responsible for the distinct pharmacological properties of the unique cerebellar NMDA receptor subtype.

Unexpectedly, the pineal gland expresses NR2C mRNA but not NMDA-sensitive $\mathrm{L}^{-}{ }^{3} \mathrm{H}$-glutamate binding sites. The lack of L- ${ }^{3} \mathrm{H}$-glutamate binding sites suggests that NR2C mRNA may not be translated in the pineal. Alternatively, the absence of a glutamate binding site may be related to our observation that neither NR1 + nor NR1 - mRNA (nor NR2A, NR2B, NR2D) was detected in the pineal (Schneider, Larson, and Monaghan, unpublished observations). Thus, the lack of $\mathrm{L}^{-3} \mathrm{H}$-glutamate 
binding may be due to the absence of NR1 subunits or the presence of a novel NR1 splice variant.

In radioligand binding studies, HQ displays two affinities in the cerebellum and it is the low-aflinity site that appears to correspond to the NR2C subunit in its affinity for HQ and unique cerebellar localization. While it is unclear what the highaffinity $\mathrm{HQ}$ site in the cerebellum represents, perhaps NR2Acontaining NMDA receptors contribute to this component. Likewise, the significance of separate high- and low-affinity HQ binding sites in other brain regions is unknown.

The anatomical distribution of the MT-like subpopulation of NMDA receptors is virtually identical to the distribution of transcripts encoding the NR2D subunit. Both display a distribution that is highly restricted to select diencephalic structures (intermediodorsal, paraventricular and paratenial, rhombiod, mediodorsal lateral, and anteroventral thalamic nuclei, the medial geniculate, the nucleus of the diagonal band, the interpeduncular nucleus, and the periaqueductal gray). In contrast, no other subunit, or combination of subunits, displays a similar pattern. These results strongly suggest that the distinctive pharmacological properties found for this NMDA receptor subtype (Beaton et al., 1992) are determined by the NR2D subunit. The observation that the NR2D and NR2C subunits show greater homology to each other than to either NR2A or NR2B subunits (Ikeda et al., 1992; Ishii et al., 1993) predicts greater structural similarities between the cerebellar and MT-like NMDA receptor subtypes. Indeed, the observation that the cerebellar and MTlike NMDA receptor populations are pharmacologically similar (both populations have lower affinities for quinolinate, homoquinolinate, CPP, and D-CPPene than other NMDA receptors) is consistent with this prediction.

\section{General conclusions}

In this report, we have demonstrated that the distribution of each of the NMDA receptor subtypes parallels the distribution of a specific NMDA receptor subunit (or combination of subunits). Furthermore, we have demonstrated that recombinant NMDA receptor subunits form heteromeric receptor complexes whose pharmacological behavior can be predicted from the study of native NMDA receptors. If one assumes a multimeric structure for the mature NMDA receptor composed of at least one member from each subunit family, as is the case for the neuronal nicotinic acetylcholine receptor (Anand et al., 1991; Cooper et al., 1992), a vast number of heteromeric complexes are possible. Thus, it is intriguing that the simple subunit combinations reported here can mimic the pharmacological properties of identified native NMDA receptor subtypes. That the NR2 subunits are predominantly responsible for the pharmacologically distinct NMDA receptor subtypes is perhaps unexpected, since NR 1 subunits (Moriyoshi et al., 1991; Monyer et al., 1992; Ishii et al., 1993) but not NR2 subunits form functional homo-oligomers and thus NR1 subunits appear to have agonist and antagonist recognition sites (assuming the absence of endogenous NR2 subunits in oocytes).

These data also suggest that different NMDA receptor radioligands should selectively label different NMDA receptor populations. The above hypotheses thus provide specific interpretations of the various reports where disparate experimental results are found when differing NMDA receptor radioligands are used (e.g., Honoré et al., 1989; Ogita et al., 1991; Savage et al., 1991; Kalb et al., 1992; Wieland, 1992).

The parallel anatomical and pharmacological properties of native and recombinant NMDA receptors described in this report suggest that there are at least four discrete populations of NMDA receptors of differing molecular composition that are heterogeneous with regard to the glutamate binding site. It has been suggested that the NR2 subunits are responsible for heterogeneity observed for the ifenprodil binding site on the NMDA receptor (Williams et al., 1993). Whether the NR2 subunit also contributes to NMDA receptor heterogeneity observed at the glycine binding domain (O'Shea et al., 1991), the PCP channel blocking site (Vignon et al., 1986; Ebert et al., 1991; Beaton et al., 1992), and the polyamine site (Reynolds and Palmer, 1991; Yoneda and Ogita, 1991) remains to be determined.

\section{References}

Anand R, Conroy WG, Schoepfer R, Whiting P, Lindstrom J (1991) Neuronal nicotinic acetylcholine receptors expressed in Xenopus oocytes have a pentameric quaternary structure. J Biol Chem 266:1119211198.

Ananthraram V, Panchal RG, Wilson A, Kolchine VV, Treistman SN, Bayley H (1992) Combinatorial RNA splicing alters the surface charge on the NMDA receptor. FEBS Lett 305:27-30.

Beaton JA, Stemsrud K, Monaghan DT (1992) Identification of a novel $N$-methyl-D-aspartate receptor population in the rat medial thalamus. J Neurochem 59:754-757.

Benke D, Marti T, Heckendorn R, Rehm H, Künzi R, Allgeier H, Angst C, Mohler H (1993) Photoaffinity labeling of the NMDA receptor Eur J Pharmacol 246:179-180.

Buller AL, White MM (1988) Control of Torpedo acetylcholine receptor biosynthesis in Xenopus oocytes. Proc Natl Acad Sci USA 85: 8717-8721.

Cheng YC, Prusoff WH (1973) Relationship between the inhibition constant $\left(K_{i}\right)$ and the concentration of inhibitor which causes 50 percent inhibition $\left(\mathrm{IC}_{50}\right)$ of an enzymatic reaction. Biochem Pharmacol 75:3099-3108.

Collingridge GL, Lester RAJ (1989) Excitatory amino acids receptors in the vertebrate central nervous system. Pharmacol Rev 41:143-210.

Cooper F, Couturier S, Ballivet M (1992) Pentameric structure and subunit stoichiometry of a neuronal nicotinic acetylcholine receptor. Nature 350:235-238.

Cotman CW, Bridges RJ, Taube JS, Clark AS, Monaghan DT (1989) The role of the NMDA receptor in central nervous system plasticity and pathology. J NIH Res 1:65-74.

Cunningham MD, Michaelis EK (1990) Solubilization and partial purification of 3-((+)-2-carboxypiperizine-4-yl)-[1,2-3 H]propyl-1phosphonic acid recognition proteins from rat brain synaptic membranes. J Biol Chem 265:7768-7778.

Durand GM, Gregor P, Zheng X, Bennett ML, Uhl GR, Zukin RS (1992) Cloning of an apparent splice variant of the rat $N$-methyl-Daspartate receptor NMDAR1 with altered sensitivity to polyamines and activators protein kinase C. Proc Natl Acad Sci USA 89:93599363.

Durand GM, Bennett MVL, Zukin RS (1993) Splice variants of the $N$ - methyl-D-aspartate receptor NR 1 identify domains involved in the regulation by polyamines and protein kinase C. Proc Natl Acad Sci USA 90:6731-6735.

Ebert B, Wong EHF, Krogsgaard-Larson P (1991) Identification of a novel NMDA receptor in rat cerebellum. Eur $J$ Pharmacol [Mole Pharmacol] 208:49-52.

Elhert FJ, Tran LLP (1990) Regional distribution of M1, M2 and nonMI, non-M2 muscarinic binding sites in rat brain. J Pharmacol Exp Ther 255:1148-1156.

Greenamyre JT, Young AB (1989) Excitatory amino acids and Alzheimer's disease. Neurobiol Aging 10:593-602.

Hollmann M, Boulter J, Maron C, Beasley L, Sullivan J, Pecht G, Heinemann $S$ (1993) Zinc potentiates agonist-induced currents at certain splice variants of the NMDA receptor. Neuron 10:943-954.

Honoré T, Drejer J, Nielsen FO, Watkins JC, Olverman HJ, Nielsen $M$ (1989) Molecular target size of the NMDA-receptor complex in rat cortex. Eur J Pharmacol 172:239-247.

Ikeda K, Nagasawa M, Mori H, Araki K, Sakimura K, Watanabe M, Inoue Y, Mishina M (1992) Cloning and expression of the $\epsilon 4$ subunit of the NMDA receptor channel. FEBS Lett 313:34-38. 
Ishii T, Moriyoshi K, Sugihara H, Sakurada K, Kadotani H, Yokoi M, Akazawa C, Shigemoto R, Mizuno N, Masu M, Nakanishi S (1993) Molecular characterization of the family of the $N$-methyl-D-aspartate receptor subunits. J Biol Chem 268:2836-2843.

Kalb RG, Lidow MS, Halsted MJ, Hockfield S (1992) $N$-methyl-Daspartate receptors are transiently expressed in the developing spinal cord ventral horn. Proc Natl Acad Sci USA 89:8502-8506.

Kutsuwada T, Kashiwabuchi N, Mori H, Sakimura K, Kushiya E, Araki K, Meguro H, Masaki H, Kumanishi T, Arakawa M, Mishina M (1992) Molecular diversity of the NMDA receptor channel. Nature 358:36-41.

Leonard JP, Kelso SR (1990) Apparent desensitization of NMDA responses in Xenopus oocytes involves calcium-dependent chloride current. Neuron 2:52-60.

Mayer ML, Westbrook GL (1987) The physiology of excitatory amino acids in the central nervous system. Prog Neurobiol 28:197-276.

Meguro H, Mori H, Araki K, Kushiya E, Kutsuwada T, Yamazaki M, Kumanishi T, Arakawa M, Sakimura T, Mishina M (1992) Functional characterization of a heteromeric NMDA receptor channel expressed from cloned cDNAs. Nature 357:70-74.

Meldrum B, Garthwaite J (1990) Excitatory amino acid neurotoxicity and neurodegenerative disease. Trends Pharmacol Sci 11:379-387.

Monaghan DT (1991) Differential stimulation of $\left[{ }^{3} \mathrm{H}\right] \mathrm{MK} 801$ binding to subpopulations of NMDA receptors. Neurosci Lett 122:21-24.

Monaghan DT, Beaton JA (1991) Quinolinate differentiates between forebrain and cerebellar NMDA receptors. Eur J Pharmacol 194:123125

Monaghan DT, Buller AL (1994) Anatomical, pharmacological, and molecular diversity of native NMDA receptor subtypes. In: The NMDA receptor, $2 \mathrm{~d}$ ed (Watkins JC, Collingridge GL, eds). New York: Oxford UP.

Monaghan DT, Olverman HJ, Nguyen L, Watkins JC, Cotman CW (1988) Two classes of $N$-methyl-D-aspartate recognition sites: differential distribution and differential regulation by glycine. Proc Natl Acad Sci USA 85:9836-9840.

Monaghan DT, Bridges RJ, Cotman CW (1989) The excitatory amino acid receptors: their classes, pharmacology and distinct properties in the central nervous system. Annu Rev Pharmacol Toxicol 29:365402.

Monyer H, Sprengel R, Schoepfer R, Herb A, Higuchi M, Lomeli H, Burnashev N, Sakmann B, Seeburg PH (1992) Hetcromcric NMDA receptors: molecular and functional distinction of subtypes. Nature 256:1217-1221

Moriyoshi K, Masu M, Ishii T, Shigemoto R, Mizuno N, Nakanishi S (1991) Molecular cloning and characterization of the rat NMDA receptor. Nature 354:31-37.

Murphy DE, Hutchinson AJ, Hurt SD, Williams M, Sills MS (1988) Characterization of the binding of $\left[{ }^{3} \mathrm{H}\right]-\mathrm{CGS} 19755$ : a novel $N$-methylD-aspartate antagonist with nanomolar affinity in rat brain. $\mathrm{Br} \mathrm{J}$ Pharmacol 95:932-938.

Nakanishi N, Axel R, Schneider NA (1992) Alternative splicing generates functionall distinct $N$-methyl-D-aspartate receptors. Proc Natl Acad Sci USA 89:8552-8526.

Ogita K, Kouda T, Suzuki T, Ohkawara A, Enomoto R, Nabeshima T, Yoneda Y (1991) Differential effects of SH-reactive agents on $\left[{ }^{3} \mathrm{H}\right]( \pm) 3-(2$-carboxypiperazin-4-yl)propyl-1-phosphonate and $\left[{ }^{3} \mathrm{H}\right]$ glutamate binding in brain synaptic membranes treated with Triton X-100. Neurochem Int 18:55-62.

O'Shea RD, Manallack DT, Conway EL, Mercer LD, Beart PM (1991) Evidence for heterogeneous glycine domains but conserved multiple states of the excitatory amino acid recognition site of the NMDA receptor: regional binding studies with $\left[{ }^{3} \mathrm{H}\right]$ glycine and $\left[{ }^{3} \mathrm{H}\right]$ glutamate. Exp Brain Res 86:652-662.
Perkins MN, Stone TW (1983) Quinolinic acid: regional variations in neuronal sensitivity. Brain Res 259:172-176.

Porter RHP, Cowburn RF, Alasuzoff I, Briggs RSJ, Roberts PJ (1992) Heterogeneity of $N$-methyl-D-aspartate (NMDA) receptors labeled with $\left.{ }^{3} \mathrm{H}\right]-3-(( \pm) 2$-carboxypiperazin-4-yl)propyl-1-phosphonic acid (CPP): receptor status in Alzheimer's disease. Eur J Pharmacol 225: 195-201.

Reynolds IJ, Palmer AM (1991) Regional variations in $\left[{ }^{3} \mathrm{H}\right] \mathrm{MK} 801$ binding to rat brain $N$-methyl-D-aspartate receptors. J Neurochem $56: 1731-1740$.

Sakurai SY, Penney JB, Young AB (1993) Regionally distinct $N$-methyl-D-aspartate receptors distinguished by quantitative autoradiography of [ $\left.{ }^{3} \mathrm{H}\right] \mathrm{MK} 801$ binding in rat brain. J Neurochem 60:1344-1353.

Savage DD, Ortiz KA, Sanchez CF, Paxton LL (1991) Prenatal ethanol exposure increases hippocampal NMDA receptor antagonist binding in 45-day-old rats. Clin Exp Res 15:339.

Siegel RE (1989) Localization of neuronal mRNAs by hybridization histochemistry. In: Gene probes (Conn, PM, ed), pp 136-150. San Diego: Academic.

Sekiguchi M, Okamoto K, Sakai Y (1990) Glycine-insensitive NMDAsensitive receptor expressed in Xenopus oocytes by guinea pig mRNA. J Neurosci 10:2148-2155.

Standaert DG, Testa CM, Penney JB, Young AB (1993) Alternatively spliced isoforms of the NMDAR 1 glutamate receptor subunit: differential expression in the basal ganglia of the rat. Neurosci Lett 152: 161-164.

Sugihara H, Moriyoshi K, Ishii T, Masu M, Nakanishi S (1992) Structure and properties of seven isoforms of the NMDA receptor generated by alternative splicing. Biochem Biophys Res Commun 185: 826-832.

vanAmsterdam FTM, Giberti A, Mugnaini M, Ratti E (1992) 3-[( 2-Carboxypiperazin-4-yl]propyl-1-phosphonic acid recognizes two $N$ methyl-D-aspartate binding sites in rat cerebral cortex membranes. $J$ Neurochem 59:1850-1855.

Vignon J, Privat A, Chaudieu I, Thierry A, Kamenka JM, Chicheportiche $\mathrm{R}$ (1986) [ $\left.{ }^{3} \mathrm{H}\right]$ thienyl-phencyclidine $\left(\left[{ }^{3} \mathrm{H}\right] \mathrm{TCP}\right)$ binds to two different sites in rat brain. Localization by autoradiography and biochemical techniques. Brain Res 378:133-141.

Watanabe M, Inoue Y, Sakimura K, Mishina M (1992) Developmental changes in distribution of NMDA receptor channel subunit mRNAs. Neuroreport 3:1138-1140.

Weiland NG (1992) Estradiol selectively regulates agonist binding sites on the $N$-methyl-D-aspartate receptor complex in the CA1 region of the hippocampus. Endocrinology 131:662-668.

White MM, Mayne KM, Lester HA, Davidson N (1985) MouseTorpedo hybrid acetylcholine receptors: functional homology does not equal sequence homology. Proc Natl Acad Sci USA 82:48524856.

Williams K, Russell SL, Shen YM, Molinoff PB (1993) Developmental switch in the expression of NMDA receptors occurs in vivo and in vitro. Neuron 10:267-278.

Wisden W, Morris BJ, Hunt SP (1991) In situ hybridization with synthestic DNA probes. In: Molecular neurobiology: a practical approach (Chad J, Wheal H, eds), pp 205-225. New York: Oxford UP.

Yamazaki M, Mori H, Araki K, Mori K, Mishina M (1992) Cloning, expression and modulation of a mouse NMDA receptor subunit. FEBS Lett 300:39-45.

Yoneda Y, Ogita K (1991) Heterogeneity of the $N$-methyl-D-aspartate receptor ionophore complex in rat brain, as revealed by ligand binding techniques. J Pharmacol Exp Ther 259:86-96. 